\title{
Clustering occupational classes by educational structure
}

Citation for published version (APA):

de Grip, A., Groot, L. M. J., \& Heijke, J. A. M. (1987). Clustering occupational classes by educational structure. Researchcentrum voor Onderwijs en Arbeidsmarkt, Faculteit der Economische Wetenschappen. ROA Working Papers No. 2E https://doi.org/10.26481/umarow.198702E

Document status and date:

Published: 01/01/1987

DOI:

10.26481/umarow.198702E

Document Version:

Publisher's PDF, also known as Version of record

\section{Please check the document version of this publication:}

- A submitted manuscript is the version of the article upon submission and before peer-review. There can be important differences between the submitted version and the official published version of record.

People interested in the research are advised to contact the author for the final version of the publication, or visit the DOI to the publisher's website.

- The final author version and the galley proof are versions of the publication after peer review.

- The final published version features the final layout of the paper including the volume, issue and page numbers.

Link to publication

\footnotetext{
General rights Owners
rights.

- You may freely distribute the URL identifying the publication in the public portal. please follow below link for the End User Agreement:

www.umlib.nl/taverne-license

Take down policy

If you believe that this document breaches copyright please contact us at:

repository@maastrichtuniversity.nl

providing details and we will investigate your claim.
}

Copyright and moral rights for the publications made accessible in the public portal are retained by the authors and/or other copyright owners and it is a condition of accessing publications that users recognise and abide by the legal requirements associated with these

- Users may download and print one copy of any publication from the public portal for the purpose of private study or research.

- You may not further distribute the material or use it for any profit-making activity or commercial gain

If the publication is distributed under the terms of Article $25 \mathrm{fa}$ of the Dutch Copyright Act, indicated by the "Taverne" license above, 


\title{
CLUSTERING OCCUPATIONAL CLASSES
}

BY EDUCATIONAL STRUCTURE

\author{
ROA-W-1987/2E
}

A. de Grip, L.F.M. Groot, J.A.M. Heijke

RESEARCH CENTRE FOR EDUCATION AND LABOUR MARKET

Faculty of Economic Sciences

Rijksuniversiteit Limburg

Maastricht, December 1987 


\section{Contents}

1. Introduction 1

2. Occupation areas and labour-market forecasts 4

2.1. The importance of the relation between education and occupation for educational and occupational choices 4

2.2. The importance of the relation between education and occupation for labour-market forecasts

Pag

4

3. Cluster analysis 10

3.1. Introduction 10

3.2. The selection of a (dis) similarity criterion 11

3.3. The selection of a clustering method 14

3.4. The selection of a clustering algorithm 15

4. The data material used 19

5. Research results 22

5.1. Clustering results 22

6. Conclusions 29

Literature 33

Annexes 


\section{INTRODUCTION}

In its recent report "Advies informatie werkgelegenheidsstructuur" (Advisory memorandum on the information available about the employment structure" (SER 1987), the Socio-Economic Council points out that owing to the scarcity of information available to actors on the labour market, quantities and prices are not properly adjusted; that in turn causes a poor match of supply and demand. The report blames on the one hand the educational system for its inadequate response to changes on the labour market. The fast developing information technology, for example, has greatly changed professional structures, but the educational system has failed to supply a sufficient number of skilled informatics staff. On the other hand, the SER report points out that the failing educational system is not the only cause of frictions on the labour market. Indeed, the educational system cannot be expected to respond adequately unless changes in the professional structure are brought to its notice in good time, that is to say, unless the nature and volume of the changes can be forecast with reasonable reliability. Now developments on the labour market are particularly hard to forecast and quantify. Many forecasting labour-market models presuppose simple and stable relations, which makes them too rigid to do justice to the adjusting capacity and dynamics of the real developments on the labour market. One attempt to improve on the traditional 'manpower-requirements approach' is flexibility research, which sets out to establish how far workers with the same training are employed in different functions or occupations. Only sporadically does there seem to be an exclusive 'direct' relation between a certain education and a certain occupation, in fact only on the so-called 'craft markets' (Doeringer \& Piore 1971).

Occupational flexibility on the labour market would imply that there are possibilities for workers to respond, by substitution and mobility processes, to shifts in the composition of demand for labour. However, to draw the conclusion that such flexibility would make labour-market forecasts superfluous would be a mistake. Obviously the potential flexibility on the labour market is limited. Vocational lore distinguishes 'occupational ranges' (Pere 1986). By the occupational range of a given education is understood the set of occupations to which that 
education gives access. They will be occupations necessitating the performance of more or less similar tasks corresponding to the the knowledge and skill provided by that particular education. Labourmarket forecasts for the occupational ranges distinguished on the labour market are therefore indispensable to study guidance.

In that view, the two-digit International Standard Classification of Occupations (ISCO) used by the CBS is not an adequate basis for labourmarket forecasts, for it combines, for instance, in one class nurses, doctors, dentists and veterinarians, professions which obviously recruit their staff from entirely different training schools. On the other hand, labour-market forecasts for the 310 occupational groups distinguished on the three-digit level are often too specific and liable to distortion owing to the potential mobility of staff between the groups.

Therefore, our aim is to establish occupational ranges by a so-called cluster analysis, based on the training profiles of the occupational groups distinguished. The underlying assumption is that occuational groups with similar training profiles belong to the same labour-market segment. However, the possibility should not be excluded that in practice other factors also contribute to the segmentation of the labour market. Indeed, the theory of labour-market segmentation points out that sex, race and age are important barriers between labour-market segments. (see, among others, Doeringer \& Piore 1971). However, from research by Teulings and Vriend (1987), such background characteristics appear to carry far less weight than training, perhaps because training is correlated with sex and race. Therefore, to establish occupational ranges by the training profiles of occupational groups alone, seems justified, at any rate for the moment.

Consider also that the occupational range is not a static fact, but tends to change in the course of time, for instance owing to developments on the labour-market. For one thing, the recruiting strategy pursued by employers tends to be more stringent in times of unemployment than in times of labour shortage. Therefore, occupational ranges cannot be established once and for all; the process will have to be repeated at regular intervals.

The present note is organised as follows. Chapter 2 considers what information is needed to make the right educational and occupational choice (section 2.1) and goes on to discuss the (in)adequacy of labour- 
market forecasts (section 2.2). Chapter 3 explains the technique of cluster analysis employed in this study and the choice of a (dis)similarity criterion (section 3.2), the clustering method as such (section 3.3), and the clustering algorithm (section 3.4). Next, chapter 4 discusses the data material used. Chapter 5 presents the outcomes of the cluster analysis. Finally, chapter 6 briefly evaluates the research. 


\section{OCCUPATIONAL RANGES AND LABOUR-MARKET FORECASTS}

\subsection{The importance of the relation between training and occupation for educational and occupational choices}

To possess school certificates is important to get a job. In humancapital theory, one's education is taken as an indication of the knowledge and skills acquired by formal schooling. That knowledge and those skills can be used on the workfloor and thus reflect an employee's productivity. However, how far specific skills acquired during formal education are actually needed to practise a given profession, is questionable. The specialisation of production processes and the division of tasks have given rise to jobs highly specific to the industry concerned, and because there are probably no training courses preparing directly for such jobs, corporate training is the solution. People are not recruited for one specific function but are supposed, as employees of a company, to perform different functions in the course of time. To workers associated with an intra-industry submarket, the discrepancy between the required and the available qualifications in their present function is of minor importance. What matters is their qualitative potential and the characteristics associated with long-run mobility and flexible employability in various functions. The corporate training system enhances such flexible employability and mobility, and at the same time makes the company to some extent independent of the regular educational system (Doeringer \& Piore 1971).

If employees are to fulfil different functions and to be kept in the company for quite some time, the company has an interest in recruiting the right persons. One consequence of internal labour markets is that specific abilities are not so much in demand as 'trainability' of workers and the right personal and behavioural characteristics. Under conditions of incomplete information, the most reliable indications of a worker's usefulness are his school certificates. In that sense, school certificates thus function as a kind of screening device (Thurow 1975).

In flexibility studies the implicit assumption is that certain (professional) trainings make people essentially eligible for several types of jobs. The question is, are the tasks to be carried out in 
different production processes similar, or is there, after all, much similarity in the various types of training? In practice, all technical training courses can supply staff for jobs requiring a technical insight, because they all provide training in technical understanding and technical skills. In general, many training courses have certain elements in common, which makes for flexibility. Moreover, in many occupations the tasks are so specialised that some form of 'onthe-job training' is anyhow indispensable. In that case people can be recruited from various training schools, the type of training being less important than the level. Various academic courses are clear examples: especially managers and executives come from a wide range of scholastic disciplines can be found.

The implications for the choice of education or profession are as obvious as important. Indeed, several educational routes appear to lead to the same occupation, and mostly a given education gives access to more than one occupationon. However, that truth should not lead us to jump from one extreme point of view (the so-called 'naive model' assuming a direct relation between occupation and training) for another, namely, the assumption of a labour market of almost unlimited flexibility, which would make the choice of study completely immaterial.

Indeed, that assumption would not be plausible either, given the wide divergence between the employment rates of workers with different types of training, and also the present serious shortage of several categories of automation experts. A more meaningful approach is the 'occupational theory', which assumes that each type of education is associated with a range of occupations. That view presupposes a certain flexibility among workers with a given education, but limits their potential to a finite number of occupations.

One way to establish what occupations correspond to a given education would be to investigate thoroughly curricula and function contents. That would entail the separate study of every training course and every occupation, a cumbersome procedure. For the present study a more practical approach has been chosen, in fact a short cut to the general picture.

The train of thought is as follows. Ask an a-select number of professionals from a given occupational group what education is required to fulfil their function adequately, and what alternative types of 
education might be satisfactory as well. If, for instance, most professionals of that group have a technical education and a minority a general education, the odds are that the technical courses from which currently many professionals are recruited, will be mentioned as the required education, with general types of education as alternatives. On the other hand, a profession might draw its people not from one particular educational category, but from schools differing in level as well as discipline. When such a professional group is questioned, chances are that no single training course will emerge as required education, but that that many different courses are mentioned and many alternatives pointed out.

In either case, the outcome of the survey reflects the present distribution of training categories among occupations. In other words, the survey of an occupational group produces approximately the educational profile of that occupation as prevailing at the time of the survey. If two occupations have the same educational profile, the survey results will be the same, and the two groups can be combined. The same approach can be followed to survey people from one training category. When asked for what occupations their education has prepared them, the respondents are likely to mention, beside their own occupation, some alternative ones, for instance those which their former class mates have come to accept. The expectation is, therefore, that the survey results will reflect the range of various occupations supported by a type of education. In actual fact, that range represents the choices essentially provided for by that type of education.

\subsection{The importance of the relation between education and occupation for labour-market forecasts}

Especially in the 'sixties, the 'Manpower-Requirements Approach' made labour-market forecasts very popular. The OECD's Mediterranean Regional Project (Hollister 1965) was one of the first studies to use that forecasting technique. Recently, Youdi \& Hinchcliffe (1985) reviewed such manpower forecasts.

One major criticism of the traditional Manpower-Requirements Approach is that it imposes one-sidedly the need, on the demand side of the labour market, for a certain volume and composition of the labour force by type of education (see, among others, Ahamad \& Blaug 1973). That 
criticism refers to the method used to forecast the demand for workers with a given education. The method is essentially as follows (the figures refer to the order of the steps; see equation 1):

1. The volume and growth of the national economy as forecast are disaggregated into separate sectoral growth figures.

2. In combination with a forecast of the development of labour productivity by sector, step 1 produces a forecast of sectoral employment in the forecast year.

3. By projecting the distribution of employment by sector among occupations (the sector's occupational structure), sectoral employment is divided among the occupations.

4. Similarly, the present distribution of employment by occupation across the different types of education (the occupation's educational structure) is projected to the future, permitting the split-up of forecast employment by occupation among the categories of education.

The entire procedure can be summarised in the following equation:

$\hat{L}_{e i j}=\frac{L e}{L i} \cdot \frac{L i}{L j} \cdot \frac{L j}{G N P j} \cdot \frac{G \underline{N P j}}{G N P} \cdot \hat{G N P}$

(4) (3) (2) (1)

with:

$L=$ employment;

$\mathrm{e}=$ education;

$i=$ occupation;

$\mathrm{j}=$ sector:

GNP = Gross National Product;

$G^{G N P}=$ volume of production in sector $j$;

indicates a forecast.

Forecasts of sectoral output and sectoral labour productivity are notoriously unreliable. Besides, especially the last step is objected to. To cite Blaug (1967, p. 281): "And here the real problem is not simply the failure to observe any unique relationship between educational background and occupational affiliation in to-day's labour force, except for those professions such as medicine and teaching where custom imposes a minimum entrance qualification, but the difficulty of separating the forces of supply from the forces of demand. What we have here is the old 'identification problem'. After all, the schooling currently associated with each occupation is as much the outcome of the supply of educated people in the past as of the history of the demand 
for qualified manpower. In any economy with a high level of agggregate demand, qualified manpower, however irrationally produced, will somehow be absorbed into employment; what we observe to;day may simply represent the misallocations of the past."

But what occupations people with a certain education will end up in, depends also on the relative scarcity of certain categories of education. Even if there is a clear relation between occupations and trainings, in the sense that the qualifications needed for the adequate fulfilment of a function match those of the outflow from the educational system, scarcity on the labour market will remain important as a factor deciding in what jobs the people concerned will eventually find themselves.

Moreover, in practice some 'on-the-job training' will always be required to take the new recruits to the desired level of productivity. Indeed, the qualifications required for the adequate fulfilment of a function will never fully match those acquired by regular education. The discrepancies will mostly be overcome in practice by learning processes within the companies. In particular where extensive on-thejob training is necessary, new workers tend to be recruited from various categories of training.

The assumption of fixed relations between sectoral employment and demand for a given category of education inherent to the traditional Manpower-Requirements Approach, mistakenly ignores the potential flexibility. With that consideration we are in the same predicament as at the end of the previous section: seemingly, labour-market forecasts are of little use to the choice of studies, because any training seems to give access to almost all occupations. Moreover, labour-market forecasts are accused of giving faulty information about the future labour-market situation because of the mobility processes which will undoubtedly occur.

In the previous section we have already pointed out that the potential flexibility on the labour market is limited to the occupational range of a type of training. Therefore, the occupational ranges should be made the basis from which to draw up labour-market forecasts. Admittedly, strongly disaggregated labour-market forecasts drawn up for highly specific occupational categories have little chance of coming true. They will become more reliable, however, if they are drawn up for the employment development of the occupational ranges that can be iden- 
tified on the labour market.

This study tries to establish these occupational ranges by the correspondence of the training structure (the 'training profile') of the various occupational groups. As pointed out in the introductory chapter, the fact should be understood that occupational ranges are liable to shift in the course of time, for instance because functions are given a different contents or school curricula are altered, or because the situation on the labour market changes.

Moreover, strictly speaking this study does not so much consider the occupational ranges of types of education as the agreement between training profiles of occupational categories. In the former case, the fan of occupations is considered to which a given education gives access; the occupational ranges of different types of education are then likely to overlap, and indeed do so in practice. The borderlines between the labour markets of various occupations are only of a relative nature. By contrast, the occupational ranges established by our approach do not overlap. That implies the existence of absolute borderlines between the labour-market segments identified. In our approach, forecasts made for occupational ranges consider only the occupational mobility within those ranges. 


\section{CLUSTER ANALYSIS}

\subsection{Introduction}

Cluster analysis is a general term for a wide array of statistical techniques used to group objects in homogeneous sub-groups on the basis of similarity. The term 'cluster' refers to the grouping of objects by means of an algorithm. The basis of our cluster analysis is a data matrix of 310 occupations and 65 categories of education. This data matrix can be considered a two-way table, each row referring to an object (in our case an occupation), and each column to a variable (in our case a type of education). An occupational group's education profile is defined as the distribution of those practising the occupation in question across the types of education distinguished. The contents of the cells are called scores; they indicate the size of the share of a given type of education in an occupational group. The sources of the data are the CBS Labour-Force Counts of 1985 (see also section 4$)$.

To combine occupations because they have similar educational profiles seems logical; full homogeneity within occupational clusters is unlikely. Nevertheless we aim at the greatest possible homogeneity within the clusters, the underlying idea being that each separate cluster represents a sub-market.

Obviously, occupational groups with corresponding educational profiles cannot be established by hand. The most appropriate statistical technique is cluster analysis. However, the method requires some choices, for the clustering toolbox provides many possibilities. The choices made in the present investigation will be explained and motivated in the next two sections. Section 3.2 justifies the choice of the (dis)similarity criterion. Section 3.3 deals with the choice of a clustering method appropriate to the purpose. Section 3.4, finally, explains the choice of the clustering algorithm. 


\subsection{The selection of a (dis) similarity criterion}

The purpose of a cluster analysis is to separate groups of comparable objects from others, so that objects within one cluster are more alike than objects of different clusters. Now there are several criteria by which to measure similarity.

The selection of a similarity criterion can be explained best by representing the educational profile of an occupational group (which is a row from the data matrix) as a vector in a multi-dimensional space. There are, in all, 310 occupational groups, which generate as many vectors or points in a space of which the number of dimensions is determined by the number of types of training distinguished. A vector, then, is nothing but the spatial representation of the educational profile of one single occupation. The existence of separate submarkets, that is to say occupational groups, recruiting their workers from the same types of training, is now supposed to become manifest by the fact that the cloud of points is not scattered at random across the space, but more concentrated in some areas than in others. A cluster of occupations thus means that the corresponding vectors are situated in a narrowly limited space. To identify such clusters, the remoteness or closeness of the vectors from or to one another must be represented by a measure. Three criteria can be operated.

The first criterion, the distance measure, fits well in the spatial approach described above. It is, in fact, a measure of dissimilarity: a higher value indicates less similarity. Among the distance measures, the squared Euclidian distance is the one most frequently used. The squared distance between occupations $h$ and $k$ based on the difference in the representation of the types of training $j(j=1 \ldots$ m) reads:
(1) $D^{2} h k=\Sigma_{j}$
$\left(x_{h j}-x_{k j}\right)^{2}$ en
(2) $D_{h k}=\sqrt{D^{2} h k}$

where $x_{h j}=$ the share of training type $j$ in occupation $h$. This distance criterion has the advantage of permitting a clear interpretation. If two occupational groups do not share a single type of training from which to recruit workers (one occupation recruiting from technical and 
the other from agrarian training courses, for instance ${ }^{1}$ ), the distance between them is maximum, and positively proportionate to the sum of the length of both vectors. The length of a vector is called the norm. The norm is greatest, and equal to 1 , if the entire occupational group has had one and the same education. If the educational profile is expressed in shares, the maximum (squared) distance between two occupations equals two (namely, the sum of both norms), and the minimum distance equals 0 (the case of both occupations having identical educational profiles). An additional advantage of the squared Euclidian distance is that the squaring gives greater weight to relatively large differences in the educational profiles. In addition, the distance criterion can be split into three components (see the Appendix). The first component is the difference in level, that is, in the average value of the objects' profiles ${ }^{2}$. The second component is the difference in variance, that is, the degree to which the values of a profile diverge from the level. The assumption is that the variance is smaller as an occupation recruits from more training categories 3 . The last component of the distance criterion is the shape of the profile. The assumption is that if the scores of profiles are equal in rank (in a ranking from the highest to the lowest share), the profiles will be rather similar in shape.

10r, both occupations recruiting from technical training courses, but one taking the lower-skilled and the other the higher-skilled.

2 Because in this study the education profile is expressed in shares in the total number of employed in an occupational group, the sum always adding up to 1 , the level of each profile is equal to $1 / \mathrm{m}$, $\mathrm{m}$ being the number of training types distinguished.

${ }^{3} \mathrm{~A}$ distinction should be made between the notions of variance and dispersion. The dispersion is greater as an occupation recuirts from more types of training. In this paper, the $n$ otion of variance has its normal statistic meaning. The variance indicates how far individual values diverge from the average value. The variance is therefore greater if only one type of training is represented in the occupation (in that case the dispersion is small) than if all types of training are equally represented (in which case the dispersion is great). Variance and dispersion of a profile appear to be closely associated with the norm of the vector representing that profile. The greater the norm, the greater the variance and the smaller the dispersion. In the case of highly unequal representations, the norm of the vector is almost equal to 1 , and in the case of equal representation it is above zero but below 1 . 
The second criterion, the correlation coefficient, is a similarity criterion and can be represented by the following formula:

(3) $Q_{j k}=$

$$
\Sigma_{j}\left(x_{h j}-x_{h}\right)\left(x_{k j}-x_{k}\right)
$$

$$
\Sigma_{j}\left(x_{h j}-x_{h}\right)^{2} \Sigma_{j}\left(x_{k j}-x_{k}\right)^{2}
$$

Once more, the interpretation is clear. The correlation coefficient varies from -1 to 1 , a coefficient of 1 meaning that both occupations have the same educational profile, and a coefficient of -1 that the educational profiles show no similarity at all. The correlation coefficient refers only to the shape of the profile (the third component of the distance criterion), for with this criterion everything is as it were measured in divergence from the average and corrected for the standard error (see equation (3)). Therefore, with this criterion the effect of level and variance differences is undone, only the difference in shape remaining. When two profiles are very similar in shape, the correlation coefficient is high. If all objects have the same level (see footnote 2), the choice between the two criteria implies a choice between clustering by differences of variance and shape (the distance criterion) and clustering by differences in shape only (the correlation coefficient).

The third criterion is the cosinus of the angle made by two vectors. If two occupations are supported by the same types of training, the vectors follow very nearly the same direction in space and therefore make a smal1, acute angle. In the approach followed here the cosinus may vary between 0 (the two vectors are orthogonal, that is, at right angles) and 1 (the similarity is perfect: both vectors have the same direction). A disadvantage of this criterion is that, unlike the distance criterion, it does not take the length of the vectors (the norm) into account. The difference with the correlation coefficient is slight. With the correlation coefficient, the scores are measured by their divergence from the average and corrected for the variance difference. With the cosinus criterion the scores are not measured in terms of divergence from the average (compare equations (3) and (4)).

(4) $\operatorname{Cos}(h, k)=\Sigma_{j} x_{h j} x_{k j} / \sqrt{ }\left\{\left(\Sigma_{j} x_{h j}{ }^{2}\right)\left(\Sigma_{j} x_{k j}{ }^{2}\right)\right\}$

Having weighed the advantages and disadvantages of the three criteria, 
we find that for the present proposition (that is, to combine occupational groups by similarity in educational profiles, in terms of the proportion of people trained in a certain way in the total number engaged in an occupation), the distance measure is to be preferred. The principal disadvantage of the correlation coefficient and the cosinus criterion is that they leave out of account the difference in variance or dispersion (that is to say, the number of training categories from which an occupational group can recruit workers). Occupations for which the type of training is of minor importance for adequate performance, for instance those for which a short period of traineeship is sufficient, can recruit from a great many types of training. The dispersion is wide, the variance (and hence the norm of the vector) narrow. Nevertheless, by the cosinus criterion or the correlation coefficient these occupations may be qualified as totally dissimilar if grosso modo they recruit from different types of training. The distance criterion makes it possible for such occupations to end up in the same cluster, namely, the one labelled with a very loose relation between occupation and training.

\subsection{The selection of a clustering method}

In choosing a clustering method, two aspects must be considered:

1. whether to prefer a hierarchical or a non-hierarchical method;

2. whether to choose an agglomerative or a dividing technique for the classification.

To 1. There is a wide choice of hierarchical-agglomerative clustering methods, against only a few non-hierarchical ones. Successive rounds of hierarchical clustering make combinations on different 'levels'. objects combined in the first rounds are more closely related than objects combined in subsequent rounds.

The few non-hierarchical methods available are mostly iterative techniques, revising a given division until an optimum is reached. One disadvantage of these techniques is that the calculations involved take relatively much time. Moreover, there has to be an initial division from which to move to perfection, but unfortunately we have no prior knowledge about clusters of occupations. For that reason, a hierarchical clustering method is preferred.

To 2. An agglomerative technique starts by combining all objects in a 
sequential, comprehensive cluster, while a dividing searching method works the other way round. With most hierarchical-agglomerative methods a corresponding tree structure can be generated, which makes the cluster organisation easy to survey.

In general, the process starts with calculating the matrix of distances or correlations between all pairs of objects. The most closely related pair (of objects) is worked into the matrix as a new object, that is to say, all distances and correlations between the remaining objects and the new cluster are re-calculated. The matrix is then scanned anew for the two objects which have become the closest related. The process can in principle be repeated until all objects are combined into one or more clusters. From the fact that most clustering programmes work by agglomeration, that appears to be a more convenient procedure than the division of a cluster into smaller ones.

\subsection{The selection of a clustering algorithm}

Six algorithms are known, all associated with the hierarchicalagglomerative methods. They differ in the way they measure the similarity between objects or clusters. They all satisfy the 'recurrence formula' of Wishart (1969a), reading as follows: Suppose objects $i$ and $j$ are combined to $a$ new cluster $k$. Then the distance between $k$ and a second cluster $h$, represented by $D_{h k}$, can be written as the sum of the distances within the cluster according to

(5) $D_{h k}=A * D_{h i}+B * D_{h j}+C * D_{i j}+D *\left|D_{h i}-D_{h j}\right|$;

$A, B, C$ and $D$ being the parameter values, which vary with the cluster algorithm chosen, as indicated in table 1.

\begin{tabular}{l|c|c|c|c} 
& $A$ & $B$ & $C$ & $D$ \\
\hline Single & $1 / 2$ & $1 / 2$ & 0 & $-1 / 2$ \\
Complete & $1 / 2$ & $1 / 2$ & 0 & $1 / 2$ \\
Average & $n_{j} /\left(n_{j}+n_{j}\right)$ & $n_{j} /\left(n_{j}+n_{j}\right)$ & 0 & 0 \\
Centroid & $n_{j} /\left(n_{j}+n_{j}\right)$ & $n_{j} /\left(n_{j}+n_{j}\right)$ & $-n_{j} n_{j} /\left(n_{i}+n_{j}\right)^{2}$ & 0 \\
Median & $1 / 2$ & $1 / 2$ & $-1 / 4$ & 0 \\
Ward & $\left(n_{h}+n_{j}\right) /\left(n_{h}+n_{k}\right)$ & $\left.\left(n_{h}+n_{j}\right) / n_{h}+n_{k}\right)$ & $-n_{k} /\left(n_{h}+n_{k}\right)$ & 0
\end{tabular}


Table 1: Parameter values of the recurrence formula.

The choice of method becomes more important as educational profiles are less centred around a limited number of cores. In other words, with a cloud of points scattered across space at random, different methods produce in widely divergent results. The results depend on the method applied (the method is not neutral). If, on the contrary, the profiles show some clear cores (that is to say, concentrations in the cloud of points), most methods will give the same results. So, if we conveniently assume that our data material is intermediary, the choice of the method to be applied is important. Below, the six methods will be judged by their advantages and disadvantages, the criterion being the formation of the most homogeneous clusters of occupational groups possible.

The Single-linkage method is least suited to our purpose. Clusters are combined by the shortest distance between two objects of either cluster. The clusters thus formed are, in spatial perspective, elongated. Each member of an elongated cluster is more similar to one other member of the same cluster than to any other object not in it. The other methods lead to compact clusters, of which all members are more alike to one another than to objects from other clusters.

The Complete-linkage method pairs off the clusters for which the two whose most remote objects in either are closer together than in any other pair, in other words, for which the diameter of the space comprising all elements of both clusters is smallest. This is a kind of Minimax principle, in that the two clusters are combined whose most different objects are more alike than with any other pair.

The Average-linkage algorithm takes care that the distance from any object of a cluster to all other objects of the same cluster is smaller than the distance to objects not belonging to that cluster. The distance between two clusters is calculated as the average of the distances between all possible pairs from either cluster. The method is 
in fact a compromise between single and complete linkage.

With the Centroid-cluster algorithm, the distance between the cores ('cluster midpoints') determines the combination. The core of a cluster is calculated from the co-ordinates of all objects belonging to it. The consequence is that the objects within a cluster are closer to the core of their own cluster than to that of any other cluster. Contrary to the Average-linkage method, not the distances between members of the one and members of the other clusters are decisive, but the distance to the core of a cluster.

The Median method tries to avoid one disadvantage of centroid clustering. When two groups are clustered of which the one counts considerably more objects than the other, centroid clustering lays the core of the combined group closer to the numerically stronger one, so that the profile of the smaller group is largely lost. With median clustering, the new core is calculated from the cores of the groups to be combined as if they were of equal size. However, the median approach has the greater disadvantage of allowing the profile of the smaller cluster to distort considerably that of the larger one.

The Minimal-variance method developed by Ward takes into account that groups become less homogeneous as more objects are added to them. The method keeps the variance within a group at a minimum, at the cost of the optimum variance between groups. Before an object is allotted to a cluster, the consequences for its inner homogeneity are considered. The algorithm allots the object to the cluster for which the smallest inner variance results.

In our case, a clustering method must satisfy the condition that the clusters be as homogeneous as possible. That condition is fulfilled best by the Ward method. Centroid and Median clustering have the additional drawback that homogeneity does not invariably decrease as the clustering proceeds. Actually, a certain step or fusion may bring about a relatively large shift of the core, while the next fusion of two clusters shows only a minute shift. With complete linkage, the resulting groups are reasonably homogeneous too, but the homogeneity is determined only by the two most heterogeneous objects within the 
cluster. In other words, the Minimax principle as applied in complete linkage is too crude. Ward's method produces very homogeneous groups; it emphasises homogeneity within each cluster, while neglecting more or less the degree to which clusters are distinguished from one another. 


\section{THE DATA MATERIAL USED}

Now that the clustering method and the clustering algorithm have been chosen, let us review the data material to which the clustering process has been applied. The basic data material is a matrix $W$, with $n$ rows and $k$ columns. The rows correspond to the three-digit occupational groups (ISCO code), the columns to the types of training distinguished (three-digit SOI code) ${ }^{4}$. The order of the occupational groups or types of training can be absolutely random. Schematically, the matrix looks as follows:

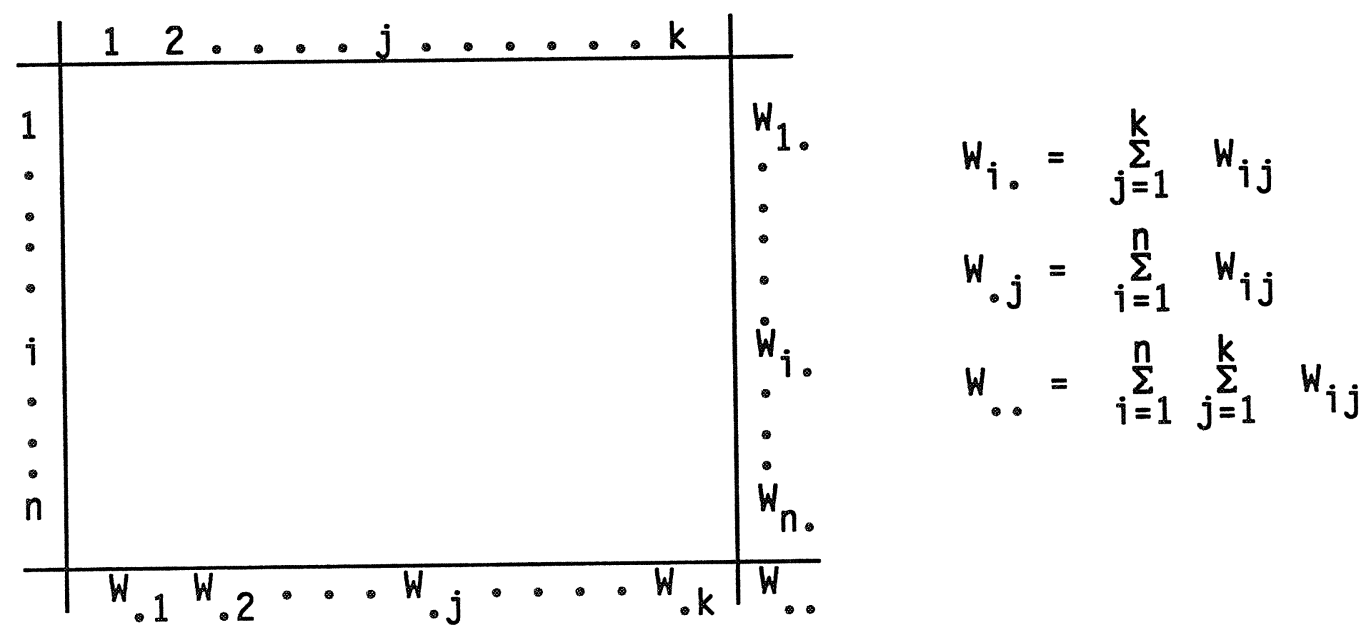

The symbols $W_{i j}$ represent employment as the number of employed persons belonging to occupational class $i$ with a j-type training. The symbols $w_{j}, w_{. j}$ and $w_{.}$. stand for total employment in occupational group $i$, total employment in training type $j$, and total employment, respective1y.

One important basis for clustering is the educational profile. It is not determined by the total number of persons employed in an occupational group but by its distribution among the types of training. A condition for good results of the clustering procedure is that all cells are expressed in figures of the same order of magnitude (scale). In our investigation, some occupational groups may be much larger than others. Especially if the distance criterion is used, the wrong scaling can produce undesired effects. There are two ways to attain good

${ }^{4}$ This classification matches closely the International Standard Classification of Education (ISCED). 
scaling and avoid undesirable effects. First, all scores $W_{i j}$ can be standardised, that is to say, calculated in terms of divergence from the average and corrected for the standard error. Second, all scores can be divided by the corresponding row totals, according to:

(6) $w_{i j}=w_{i j} / w_{j}$.

The transformed matrix $w$ then produces the fractions of all those practising occupation $i$ with j-type training. The drawback of the transformation is that there is no guarantee that after clustering each cluster comprises a sufficient number of employed persons. The transformation of the matrix for the purpose of expressing all cells $W_{j}$ in equal orders of magnitude without damaging the educational profile, thus leads to loss of information with respect to the numbers of people employed. Standardisation has the disadvantage of eliminating all information with respect to the variance within the profile, because its effect is to give all standardised educational profiles the same variance. Remember that a wider variance (small spread) means that an occupation is accessible from fewer training categories.

Another possibility is to cluster on the basis of ratios. Ratio $W^{*}{ }_{i j}$ then indicates whether i-type trainings are over- or underrepresented in occupation $j$ compared with the overall picture. The ratios $W^{*}$ are calculated as follows:

(7) $w_{i j} *=\frac{\left(w_{i j} / w_{i}\right)}{\left(w_{\circ j} / w_{. .}\right)}$

One disadvantage of working with ratios is that adequate scaling is out of the question, for the ratio may vary from zero to several thousands. Another disadvantage is that an occupation with a relatively large ratio for a numerically not too important type of training tends to be classified by that ratio. In other words, with ratios, relatively small categories of training are given too much weight, because the number of people involved is not known any more. The opposite is true when the clustering procedure is based on shares instead of ratios. In that case, the relatively large training courses get more weight because the 
inner variances ${ }^{5}$ probably increases with the number of workers they supply to various occupations. If $k$ educational categories are distinguished, there will be $k$ variables by which to cluster the occupations. A variable has more influence as the variance within it increases. Should, in the extreme case, the variance within a variable be 0 , that is to say, should this training make equal contributions to all occupations in terms of shares, then this variable offers no handle for a distinction between occupations, and its influence is zero. That characteristic and the possibility of clear interpretation have induced us to cluster occupations by the shares of training types in occupations rather than by ratios.

${ }^{5}$ The notion of variance appears in two different contexts here. A distinction can be made between variance within an occupation (that is, the variance of the educational profile), and variance within a type of training. In an occupation-bytraining matrix, the former corresponds to the variance within a row and the latter with that within a column. 


\section{RESEARCH RESULTS}

\subsection{Clustering outcomes}

On the most disaggregate level, 65 types of training are distinguished. They can be classified by level and by discipline (branch of study). In our investigation, four levels and fourteen disciplines have been distinguished. Sometimes the discipline automatically exclude some levels, for instance with quaternary, theological and art courses, which occur only on the secondary and higher levels. Annex 1 contains a cross-reference table classifying each occupation by level and discipline according to the type of training with the highest share. From that table, in particular general and technical training courses, and to a lesser extent courses of economic orientation, appear to feature large in the training structure of the occupations distinguished. Of no fewer than 48 occupations, the greatest supporter is a general education on the basic level (primary education being the highest qualification). Among the occupations classified under the technical label, those with secondary schooling constitute the largest group (45 occupations).

Now these types of education are quantitatively very important. Together they account for the education of over two milion members of the labour force. Besides these categories, primary and secondary domestic training courses, primary retail training courses and the courses given at higher professional schools are quantitatively important. At the other end of the scale there are some courses in which only a very small number of people participate, for instance the evangelist and missionary training course (300 students), the Higher Hotel School (3000 students), the Military Academy (300 students). Evidently, a further disaggregation of the relatively large, general, technical and economic types of training would be desirable, but given the present state of the data material that is not possible. According to the Labour-Force Survey there are in the Netherlands 700,000 persons with no more than primary education and over 500,000 with a certificate of primary technical education who cannot be further distinguished. The deficiencies of the data material may also affect the classification resulting from the clustering exercise. In other words, the chosen 
division of fourteen disciplines determines in part the outcomes. A different division will lead to different results (see also Teulings \& Vriend 1987).

As suggested above, there are two dimensions to the training factor, namely the branch of studies - or discipline - and the level. In the clustering procedure that distinction was maintained. Annex 2 presents the results of a clustering analysis by branch of studies. That analysis was undertaken first, on the assumption that people are first of all artists, lawyers, technicians, etc. Since we have distinguished 14 branches of study, clustering was continued until fourteen clusters of occupations had been formed, comprising all 310 occupations.

After the completion of branch-wise clustering, a simple level criterion was applied to identify possible level clusters within the branch clusters. The level yardstick was constructed as follows: all levels of education were weighted with the number of years of effective education needed to complete the education on that leve1. Thus, elementary education values 6 , a certificate on the level of lower general secondary or elementary professional training 9, a higher general secondary, preparatory scientific or Intermediate vocational certificate 12, a certificate of higher professional education 15, and a certificate of scientific education 18 (see also the 1985 SOIclassification). Next, for each occupation the levels in terms of years are weighted with the shares these levels have in the training for the occupation. Finally, the outcomes thus obtained are scaled back to an index figure lying between 1 (elementary education) and 5 (scientific education). The sub-clusters by level of education (ON) are determined as follows:$$
E L \leq 1.5 \text { Primary school ('unskilled') }
$$$$
\text { 1.5 } \mathrm{EL} \leq 2.5 \text { MAVO (1 ower general secondary), LBO (1 ower }
$$
vocational)

2.5 $\angle \mathrm{EL} \leq 3.5$ HAVO (higher general secondary), VWO (preparatory scientific), MBO (intermediate vocational)

$3.5<E L \leq 4.5 \mathrm{HBO}$ (higher vocational)

$E L>4.5$ W.O. (scientific education)
}

In that way, a total of 40 sub-clusters emerge which could be interpreted as occupational ranges. A brief sketch of the clusters found follows now. 
The first cluster contains occupations which almost exclusively recruit staff with a technical background (see annex 2 ). The occupational group Motor-vehicle mechanics (ISC0-843), with 84 per cent of technically skilled staff, holds the lowest share of technicians in this cluster, which is indeed quite homogeneous. It contains occupations from the ISCO classification with the two-digit codes 01 (Physical scientists and related technicians), 02/03 (architects, engineers and related technicians), and 85 (electricians). When split up by level, the cluster produces four level clusters ranging from persons with a lower technical certificate to university graduates. The second cluster also contains occupations with mostly a technical background. It can be subdivided into a sub-cluster of technical occupations fulfilled partly by staff with a general education, and another in which technicians dominate but to a lesser extent than in the previous cluster. For instance, the profession of architect (ISCO021) scores highest with 82 per cent of technicians, has been classed in the second rather than the first cluster, where 84 was the lowest percentage. Shoemakers and Shoe-repairers (ISCO-801), with 44 per cent, score the lowest share of technicians. Once more, subdivision by level produces four sub-clusters ranging from those with lower vovational and lower general secondary certificates to university graduates.

The third cluster contains all occupations in which most of those employed have had a medical education. It comprises, among others, all nursing personnel, accounting for a total employment of more than 150,000. This cluster contains practically the entire ISCO 06/07 class. Subdivision by level shows that there are medical occupations with mostly secondary education (nurses and medical assistants (ISCO-593)) as well as with higher educations (higher vocational and university graduates).

The fourth cluster contains many transport occupations (among which the two-digit ISCO groups 04 (Aircraft and ships'officers) and 98 (Transport and equipment operators). For the tasks to be performed in these occupations, technical skills are very useful. Indeed, 16 per cent of the professional chauffeurs appear to have had transport training and 40 per cent a technical education. Sub-division by level produces three sub-clusters with only the lowest and highest levels of education lacking.

The fifth cluster contains nine occupations, all with an agricultural 
background; it concerns a sector of self-employed persons that is relatively unimportant in terms of employment. It contains the twodigit ISCO groups Farm managers and supervisors (ISCO code 60) and Farmers (ISCO code 61), but not the ISCO group Agricultural workers (ISCO code 62) ${ }^{6}$. From a subdivision by level, only the higher-grade agriculturalists appear to distinguish themselves from the others with an higher vocational-level education. The other sub-markets tend to recruit people with a primary or intermediary agrarian education. The sixth cluster contains all professionals with a more or less specialist laboratory training: life sciences technicians, pharmacists, optometrists and medical x-ray technicians. On this sub-market the association between training and occupation is very close. Sub-division by level separates the pharmaceutal assistants and optometrists with an intermediary education, the medical x-ray technicians and life sciences workers with an higher vocational education, and the pharmacists with their university education.

The seventh clusters is the most diversified of all. There is no common denominator. At first sight general and economic types of education appear the linking elements in this cluster, but the dietitians (ISCO code 069) are too important an exception. Cluster 7 is therefore taken as a residual category. It contains a variety of occupations, for instance authors and journalists (ISCO group 15) with a general-economic education, agricultural workers (ISCO group 62) and forestry workers (ISCO group 63), part of whom are technically trained while others have a general education, statistitians with technical or economic training, some of the managing functions (ISCO groups 20 and 21), a number of clerical occupations with a general-economic educational structure (ISCO groups 37 through 40), some commercial functions, likewise with a general-economic educational structure (ISCO groups 48 and 49), and some service functions, in particular workers with domestic training (ISCO groups 52 through 55). In employment terms, this cluster contains four large occupational groups, namely correspondence and reporting clerks (248,000 persons), shop-assistants $(219,000)$, attendants not mentioned before $(133,000)$, and charworkers, cleaners and related workers $(116,000)$. Splitting-up by level produces four sub-clusters but does not makes us much wiser.

\footnotetext{
${ }^{6}$ They are part of the seventh cluster.
} 
The eighth cluster contains all occupations belonging to the submarket on which an economic education is in demand. The majority of people in this cluster have had such an education, but there are also persons with a general of technical training. This cluster contains many commercial functions, for instance all independent shopkeepers (ISCO group 43), but also all self-employed in catering services (ISCO group 51) who in the ISCO classification come under the service label. That last fact is a good illustration of the difference between the ISCO classification by the nature (sector) of the work, and ours by educational structure. The ISCO classification allocates "small enterprise" to the sales workers and all self-employed caterers to the service functions (to which belong domestic staff as well as firefighters and policemen), but in terms of education the two groups of self-employed are hardly separable. This cluster contains three occupational groups with more than 100,000 employed, namely the stenographers and typists, the bookkeepers and cashiers and the bookkeepers, cashiers and related workers n.e.c. Division by level produces a smallish group of occupations (among them economists, accountants and system analysts) with an average HBO-level education, a large group with mostly intermediary schooling, and a group with mostly lower general secondary/LBO-educated people.

Cluster $\mathrm{nr} 9$ is very homogeneous. It contains exclusively jurists (ISCO group 12); because such professions require a university education, therefore there is no need to split the cluster into levels. This cluster clearly illustrates how much the result of the clustering depends on the disciplines chosen. The distinction of a separate legal branch of studies increases the chance of finding a specific 'legal cluster'.

Cluster ten does not need much comment either. It is the sub-market comprising all teaching personnel (compare ISCO-group 13) and can be divided into two sub-markets, respectively containing those with a higher and those with an intermediary vocational training.

The eleventh cluster contains all occupations whose practitioners have visited arts or theological schools. The occupations concerned are ministers of religion, sculptors and musicians. In terms of employment it is a tiny group. Given the fact that theological education begins at the university level, the gaps between the levels within the cluster are not very wide (only higher vocational and university graduates). 
Cluster 12 contains occupations (all belonging to ISCO class 19) which to which a socio-scientific education is conditional. The group is small in employment terms, and the differences between levels are very narrow. Only within the group of sociologists (ISCO 192) can a university level of education be identified; the other occupations are, on the average, on the higher level.

Cluster 13 comprises all occupations practised mostly by people with a general education, but also by technically trained staff. The cluster contains most of the crafts and manufacturing occupations (ISCO occupations 70 through 99 , the $7 / 8 / 9$ class). About two thirds of the 133 occupational groups which the ISCO allocates to the $7 / 8 / 9$ class are contained in this cluster; the remaining one third, consisting of metal workers (ISCO groups 83, 84 and 87) and electrotechnicians (ISCO group 85), are allocated to the first and second clusters. Classification by level shows up one cluster of occupations in which the majority have merely completed primary school, and another where the majority have obtained a low-grade certificate. Only the occupational group broadcasting station operators has an average intermediate vocational level education.

The fourteenth cluster comprises the military occupations and others associated with public order. Three out of the four occupational groups have an average education on intermediate vocational level. Only the occupational group protective service workers (ISCO 589) has an average level equal to that of lower general secondary or secondary vocational schooling.

In sum, the following conclusions can be drawn. The largest cluster in terms of occupational groups contains occupations marked by a common general education, 38 of the 81 occupations of this cluster counting mostly workers with an elementary education only, the remainder (43 groups) being mostly on the level of lower general secondary schooling. Next to this cluster with mostly general-schooling occupations (perhaps at the same time the set of unskilled occupations), there are two with mainly technical occupations. In the first, containing 23 occupational groups, technical training courses take a share of over 80 per cent; in the other just over 50 per cent. Strikingly, there is a cluster for almost any branch of studies, the domestic branch being the only one unidentifiable as such. Occupational groups containing many workers 
with domestic or industrial training are classed in a highly diversified cluster, comprising a total of 55 occupational groups; this cluster can best be characterised as one in which no single branch of education has a share of over 50 per cent, but in which general, technical, domestic and economic trainings play a role.

Technical training plays a role in the first, second and thirteenth clusters. Among the first cluster there are occupations recruiting 80 per cent of technically trained staff; the second cluster contains, besides technicians, also people with a general education (elementary or lower general secondary); the thirteenth cluster recruits mainly low-skilled workers with a general education but also people with a technical training.

After the clustering by branch of study, the differences in level were considered, an exercise that was not always meaningful. The 'legal cluster', for one, contains only three professions, mostly exercised by university graduates. No more educational levels (or intermediary forms, such as secondary/higher) have in the end been distinguished than proved meaningful. To give an example: the cluster of highly technical occupations consists of 10 occupational groups with mostly higher, and 13 with mostly secondary education. The second technical cluster can be split up into, on the one hand, occupations with intermediary and primary technical education, and on the other occupations with secondary and higher technical education. Mark that the sub-clusters become more homogeneous as the original clusters are broken down into more detail.

From annex 2, occupations with the lower-educated are to be found particularly in the clusters with a technical or general background, whereas the higher-educated occupations are spread across more branches. That is largely the result of the branch classification chosen. On the higher level more branches are distinguished than on the lower levels (see also Teulings \& Vriend 1987). The artistic discipline, for instance, occurs only on the highest level, and the theological, quaternary and paedagogical disciplines only on the secondary and higher levels. On the highest level all disciplines except the general branch of studies occur. On the lowest level, only general (primary) schooling is distinguished. 


\section{CONCLUSIONS}

This paper represents a first attempt at distinguishing labour-market segments by combining occupational groups (the three-digit ISCO classification). The criterion employed is the similarity of educational structures. Occupational groups with a highly similar educational structure are supposed to constitute a separate sub-market. Both the branch and the level of education have been taken into account. Naturally, education aspects are not alone decisive for the existence of more or less well defined sub-markets. Other factors, such as age, sex, race, region, and being employed or self-employed may also influence the dividing lines between sub-markets (Doeringer \& Piore 1971; Van Hoof \& Dronkers 1980). Probably, however, some of these factors are strongly correlated with education variables. Especially sex, race and to a lesser degree age are doubtful characteristics for distinct sub-markets. Sex and branch of studies, for instance, tend to be strongly associated. In other words, there is a measure of sexual segregation in education. In that case, the inclusion of sex as a characteristic would merely lead to multicollinearity.

The purpose of this paper has been to internalise the potential flexibility between education and the labour market in the various submarkets. This flexibility is manifest from the fact that occupational groups recruit their workers from various types of training, and on the other hand, that most types of training give access to several occupational groups.

That occupational flexibility permits easy response to the continuously changing needs on the demand side of the labour market. It means that the idea of a strict relation between education and profession - as professed in the Manpower-Requirements Approach - is discarded here. On the other hand, flexibility has its limits, a fact to be kept in mind. As far as educational and vocational guidance is concerned, it must be realised that although a given type of education gives access to various occupations, the choice is mostly limited to a certain range. Corporate training systems may extend the fan of possibilities. Scarcities and surpluses on the labour market must also be considered. The results of this paper should therefore be regarded as a snapshot, and considered against the background of the volume of on-the-job training and the tension on, and flexibility of, the labour market. 
To realise the objective mentioned above, cluster analysis has been applied. From the clustering techniques available we had to choose one that hopefully would produce the most homogeneous clusters of occupational groups. To that end we have opted, first, for Ward's method (the minimum-variance method) which minimalises the variance within groups at the price of sub-optimum variance among groups. While being as homogeneous as possible, the clusters thus formed are not always clearly distinguishable. Indeed, three quite homogeneous 'technical clusters' have emerged, two of which are more or less overlapping (the differences between the border cases of either being marginal). Next, we have preferred using the distance criterion, in order to prevent occupational groups which recruit from many different types of training from being divided among different clusters. The application of this criterion has resulted in a cluster in which labour is recruited from general, economic, domestic, technical and to a somewhat lesser extent agricultural training courses, none of them having a higher share than 50 per cent.

Finally, we have chosen to process the data material such as to obtain the shares various training types take in occupational groups rather than absolute figures or ratios. The advantage of working with shares is that the relatively voluminous branches of education receive a larger weight than the relatively smaller ones, for the weight of a given branch of education (variable) increases with the variance within that variable. A wider variance of this variable can in that respect be understood to offer better handles for distinguishing occupational groups by that variable.

The clustering results can be summarised as follows. The largest cluster (in number of occupational groups) is the one requiring mostly a general education on the elementary level: 38 out of the 81 occupations combined in this cluster are filled mostly by people with an elementary education, and the remaining 43 mostly by people with certificates of lower general secondary schooling. Two clusters comprise mostly technical occupations; technical training courses have contributed more to the first than to the second of these two.

One very broad cluster comprises a total of 55 occupational groups. It represents a sub-market to which no single branch of studies contributes more than 50 per cent, and in which general, technical, domestic and economic training courses take shares. For most branches 
of study separate clusters have been formed, however.

The clusters found reflect the disaggregation of the classification by branches of study in the SOI code. No fewer than 81 occupational groups were combined in a general/technical cluster. The explanation is that more than 40 per cent of the 1985 labour force had had a general or technical education, and that no distinction has been made between the various branches of technical training. Beside this general/technical cluster, several others have been formed for which one single branche of studies can be considered the common denominator. Separate clusters have been formed for all branches of study distinguished, except for domestic and industrial instruction, while the theological and art schools have been combined to one cluster. That there is no separate cluster for, say, domestic studies springs from the fact that, apart from the group of dieticians, no occupational group recruits significantly from that type of training. The combination of theology and arts to one cluster can be explained in a similar way: in either branch, only two occupations depend for more than half their practicians on the studies in question. In terms of employment this cluster is the smallest of all; perhaps it should nevertheless be split up into religious and artistic occupations.

Another conclusion from our investigation is that some parts of the classification developed are similar to the ISCO two-digit occupational classification, operated by the CBS. However, in the main our classification is different from ISCO in that nearly all clusters contain occupational groups from several ISCO-classes. The differences can largely be explained from the criteria by which the ISCO classification and ours have been developed. Naturally, a classification by similarity of educational profiles will be different from one by 'similarity in the nature of the activities performed ', particularly because the latter is determined mostly by the branches of activitity in which people are employed. We cite from the comments on the ISCO classification: "in general can be said that as the classification becomes less detailed, the similarity of the activities performed is of a more general nature" (page 2 of the comments). In other words, the similarity grows with more detail. In view of our results the question is warranted how the similarity of occupations reached on the quite detailed three-digit level can be reconciled with such wide differences in educational structure. 
Another remarkable fact emerging from the investigation is that the two-digit ISCO classification, makes a distinction between selfemployed in commercial functions (among whom small entrepreneurs) and self-employed in service functions (among whom those working in the catering sector). In terms of education the two groups are hardly distinguishable, and from that point of view their separation is not justified.

Our final remark concerns the aspect of levels. Unlike differences in branch of study, those in level are hierarchical. Therefore, no clustering techniques have been used to define sub-clusters by level of education; a level criterion has been constructed instead, a criterion permitting to represent levels one-dimensionally. In some clusters all levels, from the lowest to the highest, are represented, whereas with others (for instance the legal cluster) there is clearly a threshold to be overcome to gain access to the professions concerned.

With the method described, 40 sub-clusters have been formed which can be used as a basis for labour-market forecasts. Given better data material, some (sub-)clusters might be split further. A separate subcluster could for instance be made for the building trade within the thirteenth cluster; the twelfth cluster might be split into subclusters for theological and artistic occupations. Besides, the clustering results might be much improved if more disaggregate data on the workers' branches of education came available, for instance by a further division of the technical types of training. 


\section{Literature}

Ahamad, B., M. Blaug (eds.) (1973), The Practice of Manpower Forecasting; A Collection of Case Studies, Elsevier, Amsterdam.

Blaug, M. (1967), Approaches to Educational Planning, Economic Journal, vol. $77, \mathrm{pp} .262-287$.

Doeringer, P.B., M.J. Piore (1971), Internal Labor Markets and Manpower Analysis, Heath Lexington Books, Lexington.

Everitt, B. (1974), Cluster Analysis, London.

Hollister, R.G. (1965), A Technical Evaluation of the First Stage of the Mediterranean Regional Project, OECD, Paris.

Hoof, J.J. van, J. Dronkers (1980), Onderwijs en arbeidsmarkt, Sociologische monografieën, Van Loghum Slaterus, Deventer.

Lorr, M. (1983), Cluster Analysis for Social Scientists, Jossey-Bas, San Francisco.

Pere, H.M. (1986), Arbeidsmarktvoorlichting, een voorstel voor interdisciplinaire opbouw, Centrum voor Beleidsanalyse en Advies, Nijmegen.

Sheldon, G. (1985), Die berufliche und geographische Flexibilität, Ph.D. Dissertation, Beitrag 92, Nürnberg.

Thurow, L.C. (1975), Generating Inequality, Macmillan, New York.

Teulings, $C_{0}, \quad N_{0}$ Vriend (1987), Een empirische afbakening van beroepsdeelmarkten, SEO, Amsterdam.

Yondi, J., K. Hinchcliffe (eds) (1985), Forecasting Skilled Manpower Requirements; The Experience of Eleven Countries, UNESCO, Paris. 
Annex 1 Occupations classified according to highest share in level and branch of study (numbers refer to ISCO-code)

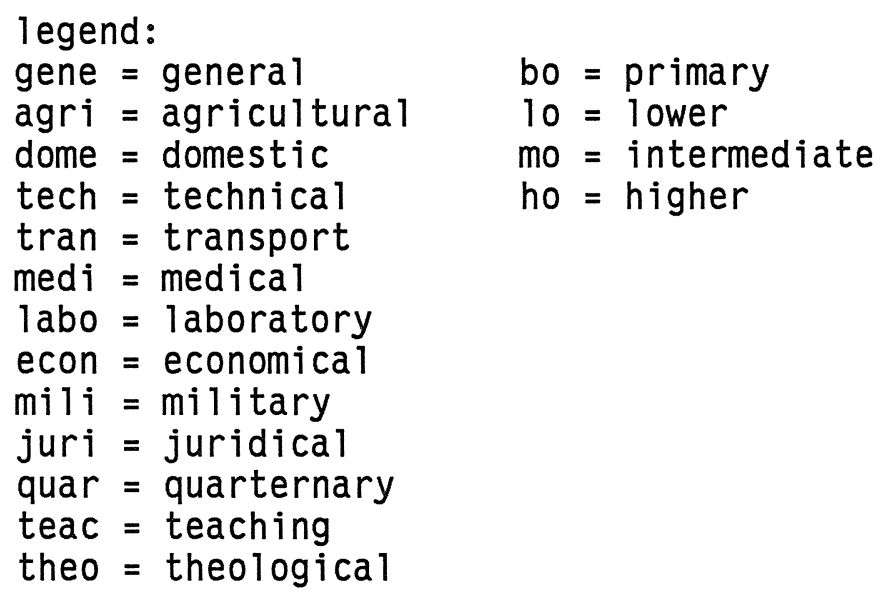




\section{Annex 2 Cluster results}

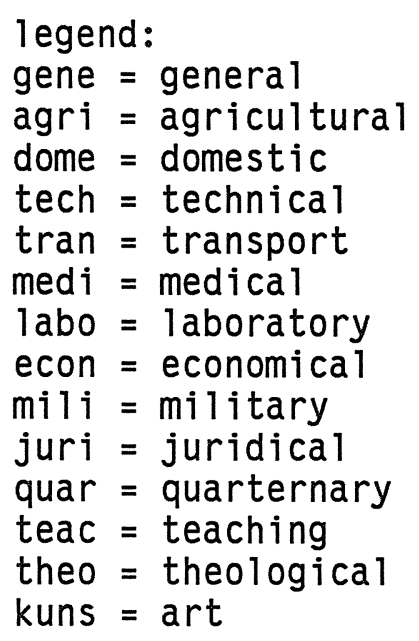

Cluster 1

ISCO GENE AGRI DOME TECH TRAN MEDI LABO ECON MILI JURI QUAR TEAC THEO KUNS

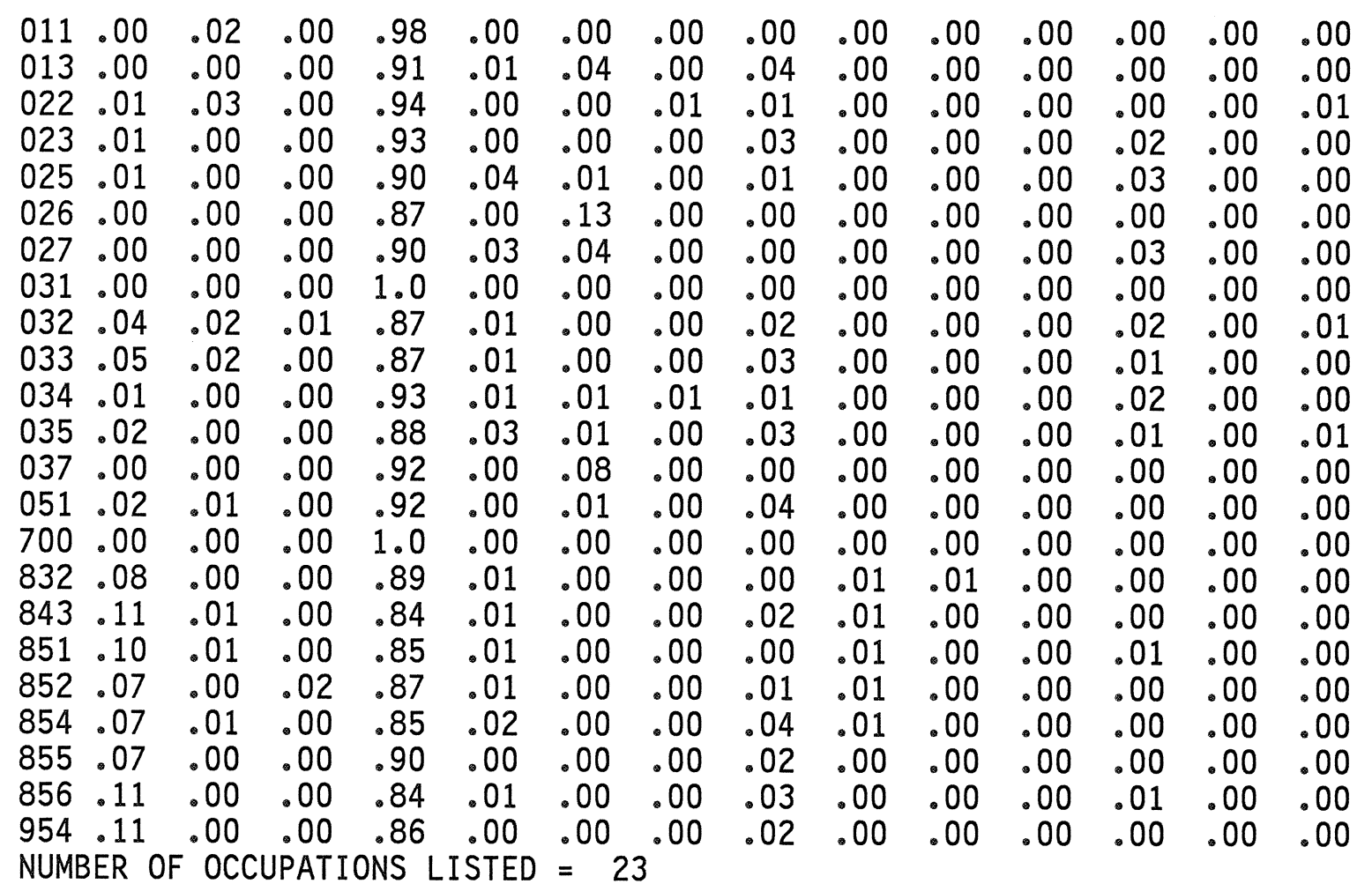
ISCO NUMBER DESCR

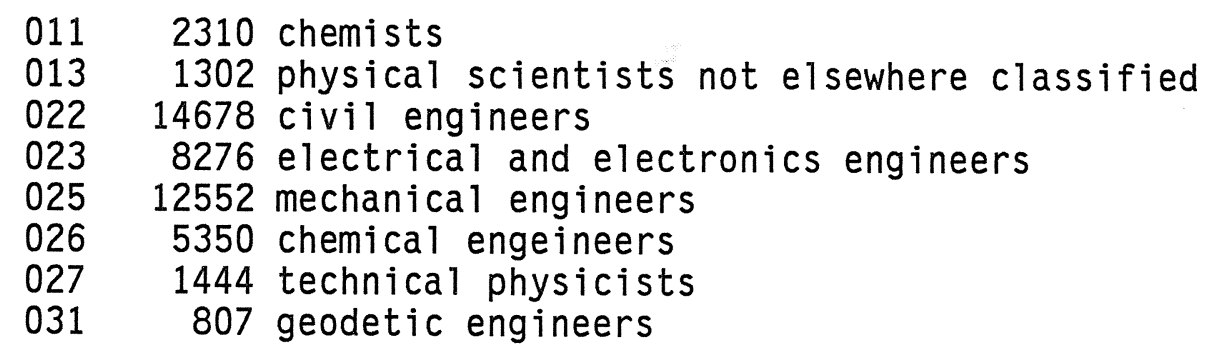


03228264 draughtsmen

03324361 civil engineering technicians

03412101 electrical and electronics engineering technicians

03514019 mechanical engineering technicians

$037 \quad 569$ metallurgists

0512893 biologists

70045 production supervisors and general foremen

8324932 toolmakers

84339599 motor vehicle mechanics

8517733 electrical fitters

$852 \quad 19376$ electronics fitters

8543200 radio and television repairmen

85540860 electrical wiremen

85610955 telephone and telegraph installers

95467214 carpenters

NUMBER OF OCCUPATIONS LISTED $=23$

ISCO LEVEL PRIMA SECON INTERM HIGHER ACAD DESCR

Scientific education

\begin{tabular}{llllllll}
\hline 011 & 4.94 & .00 & .00 & .01 & .04 & .95 & chemists \\
051 & 4.84 & .00 & .05 & .00 & .00 & .95 & biologists \\
013 & 4.76 & .00 & .04 & .00 & .12 & .84 & physical scientists n.e.c. \\
027 & 4.51 & .00 & .00 & .09 & .30 & .60 & techn. physicists \\
Higher vocational. & & & & & \\
\hline 026 & 4.48 & .00 & .00 & .06 & .39 & .55 & chemical engineers \\
023 & 4.12 & .00 & .01 & .14 & .60 & .26 & electrical engineers \\
022 & 4.08 & .00 & .01 & .14 & .61 & .24 & civil engineers \\
025 & 3.99 & .00 & .03 & .18 & .56 & .23 & mechanical engineers \\
031 & 3.87 & .00 & .00 & .33 & .47 & .20 & geodetic engineers \\
037 & 3.68 & .00 & .07 & .36 & .40 & .17 & metallurgical technicians \\
Higher general secondary/Preparatory & scientific/Intermediate vocational \\
\hline 034 & 3.31 & .00 & .03 & .64 & .32 & .01 & electrical eng. techn. \\
035 & 3.21 & .00 & .05 & .70 & .23 & .02 & mechanical eng. techn. \\
033 & 3.10 & .02 & .08 & .70 & .20 & .01 & civil eng. techn. \\
032 & 3.02 & .01 & .15 & .66 & .16 & .02 & draughtsmen \\
700 & 3.00 & .00 & .00 & 1.0 & .00 & .00 & production supervisors \\
852 & 2.86 & .04 & .16 & .69 & .10 & .00 & electronics fitters \\
854 & 2.71 & .03 & .24 & .72 & .01 & .00 & radio repairmen \\
856 & 2.64 & .08 & .21 & .70 & .01 & .00 & telephone installers \\
855 & 2.60 & .05 & .32 & .61 & .02 & .00 & electrical wiremen \\
851 & 2.52 & .10 & .30 & .59 & .02 & .00 & electrical fitters \\
Lower general & secondary/Lower vocational & \\
832 & 2.45 & .08 & .40 & .52 & .00 & .00 & toolmakers \\
843 & 2.44 & .08 & .39 & .52 & .00 & .00 & motor vehicle mechanics \\
954 & 2.30 & .10 & .50 & .40 & .00 & .00 & carpenters \\
\hline
\end{tabular}

NUMBER OF OCCUPATIONS LISTED $=23$ 


\section{Cluster 2}

ISCO GENE AGRI DOME TECH TRAN MEDI LABO ECON MILI JURI QUAR TEAC THEO KUNS

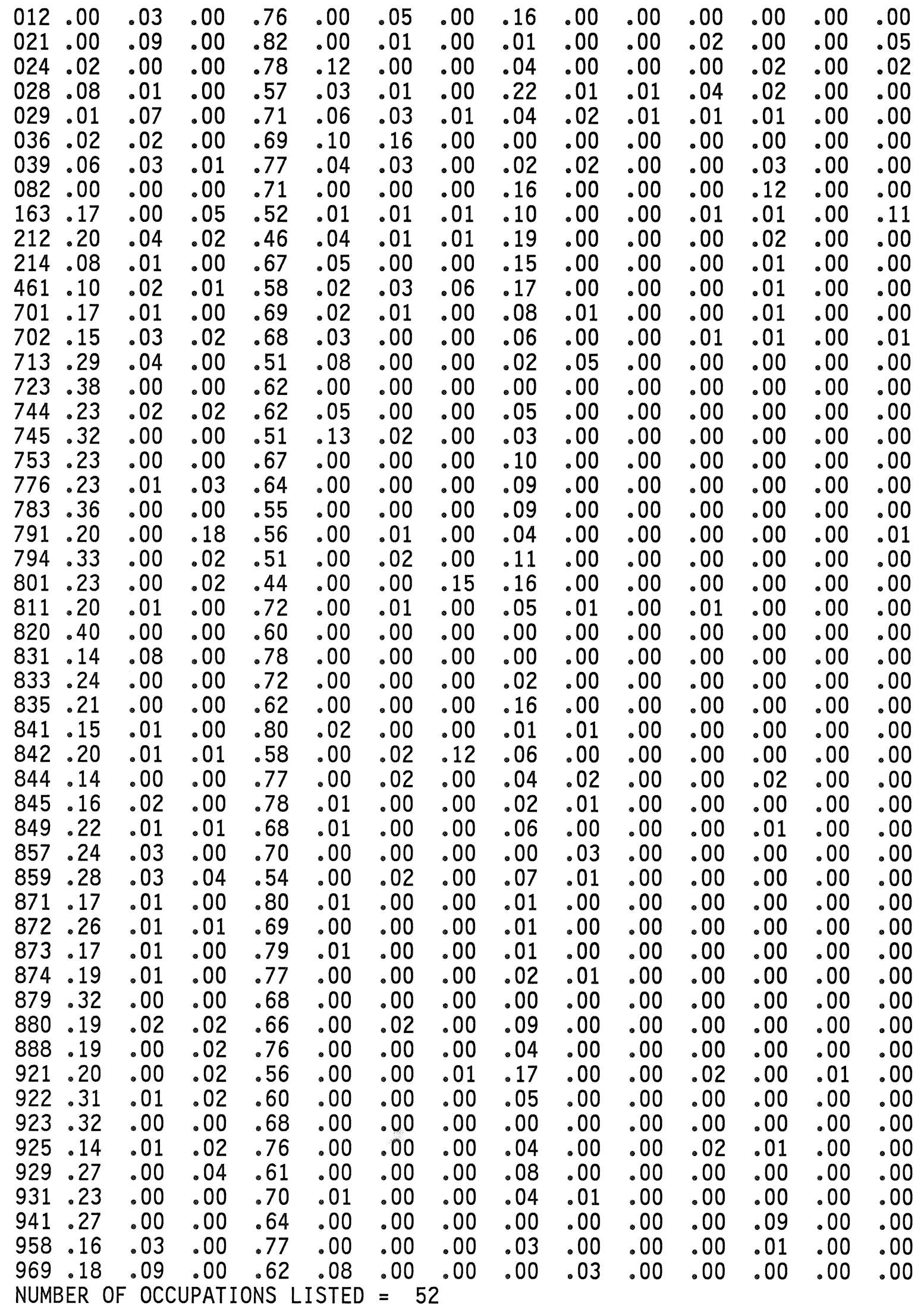


ISCO NUMBER DESCR

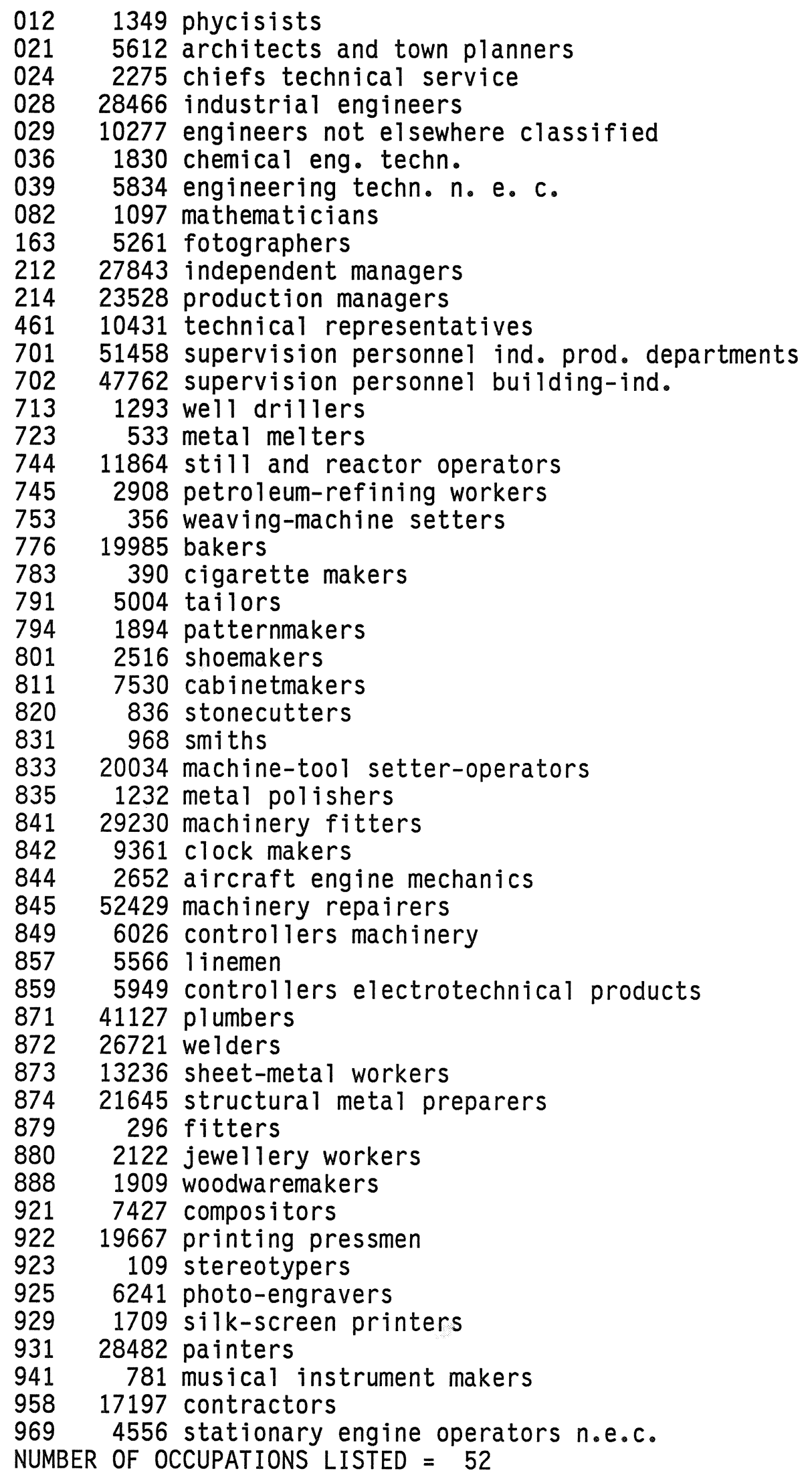


ISCO LEVEL PRIMA SECON INTERM HIGHER ACAD DESCR

Scientific education

\begin{tabular}{|c|c|c|c|c|c|c|c|}
\hline 021 & $\begin{array}{l}4.85 \\
4.51\end{array}$ & $\begin{array}{l}.00 \\
.00\end{array}$ & $\begin{array}{l}.00 \\
.00\end{array}$ & $\begin{array}{l}.00 \\
.00\end{array}$ & $\begin{array}{l}.15 \\
.49\end{array}$ & .85 & $\begin{array}{l}\text { mathematicians } \\
\text { architects and town planners }\end{array}$ \\
\hline \multirow[b]{2}{*}{$\begin{array}{l}\text { Highe } \\
012 \\
029 \\
024 \\
036\end{array}$} & $r$ voca & ional & & & & & \\
\hline & $\begin{array}{l}4.38 \\
4.21 \\
3.64 \\
3.61\end{array}$ & $\begin{array}{l}.00 \\
.00 \\
.00 \\
.00\end{array}$ & $\begin{array}{l}.16 \\
.01 \\
.04 \\
.04\end{array}$ & $\begin{array}{l}.03 \\
.13 \\
.36 \\
.31\end{array}$ & $\begin{array}{l}.08 \\
.47 \\
.53 \\
.62\end{array}$ & $\begin{array}{l}.72 \\
.38 \\
.08 \\
.02\end{array}$ & $\begin{array}{l}\text { physicists } \\
\text { engineers n.e.c. } \\
\text { chiefs technical service } \\
\text { chemical eng. techn. }\end{array}$ \\
\hline
\end{tabular}

Higher general secondary/Preparatory scientific/Intermediate vocational

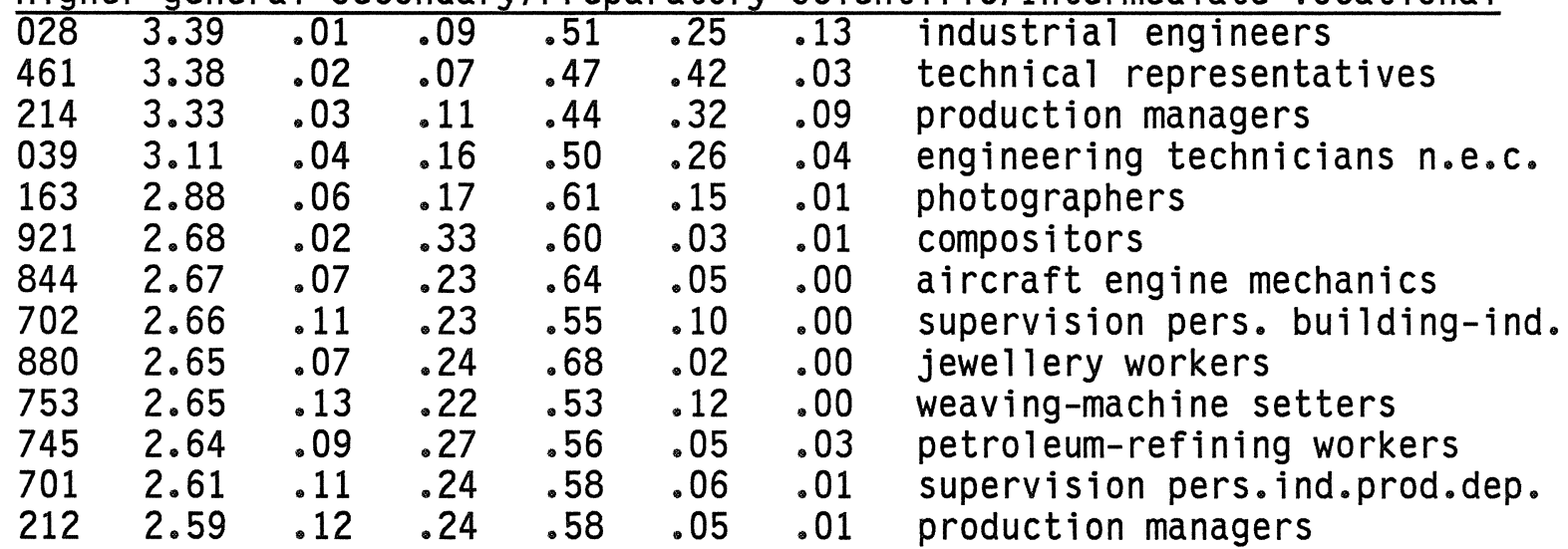

Lower general secondary/Lower vocational

\begin{tabular}{|c|c|c|c|c|c|c|c|}
\hline 842 & 2.48 & .12 & .31 & .55 & .01 & .00 & clock makers \\
\hline 925 & 2.47 & .10 & .37 & .51 & .03 & .00 & photo-engravers \\
\hline 849 & 2.47 & .16 & .27 & .50 & .05 & .01 & controllers machinery \\
\hline 801 & 2.46 & .17 & .21 & .62 & .00 & .00 & shoemakers \\
\hline 744 & 2.42 & .13 & .33 & .51 & .02 & .00 & still operators \\
\hline 941 & 2.39 & .20 & .29 & .42 & .09 & .0 & musical instrument makers \\
\hline 859 & 2.39 & .23 & .22 & .47 & .07 & .00 & controller electrotech. prod. \\
\hline 958 & 2.37 & .14 & .39 & .44 & .02 & .01 & contractors \\
\hline 841 & 2.37 & .12 & .40 & .48 & .00 & .00 & machinery fitters \\
\hline 831 & 2.36 & .14 & .36 & .50 & .00 & .00 & smiths \\
\hline 845 & 2.34 & .13 & .40 & .46 & .01 & .00 & machinery repairers \\
\hline 969 & 2.32 & .18 & .35 & .45 & .03 & .00 & stationary engine op. n.e.c. \\
\hline 929 & 2.31 & .15 & .43 & .39 & .00 & .02 & silk-screen printers \\
\hline 776 & 2.29 & .17 & .37 & .45 & .01 & .00 & bakers \\
\hline 791 & 2.28 & .16 & .42 & .40 & .02 & .00 & tailors \\
\hline 783 & 2.26 & .26 & .30 & .37 & .07 & .00 & cigarette makers \\
\hline 871 & 2.25 & .15 & .46 & .39 & .00 & .00 & plumbers \\
\hline 811 & 2.24 & .17 & .44 & .38 & .01 & .0 & cabinetmakers \\
\hline 713 & 2.24 & .21 & .38 & .38 & .03 & .00 & well drillers \\
\hline 873 & 2.23 & .14 & .50 & .36 & .00 & .00 & sheet-metal workers \\
\hline 874 & 2.22 & .15 & .50 & .35 & .01 & .00 & structural metal preparers \\
\hline 888 & 2.21 & .16 & .49 & .31 & .03 & .00 & woodwaremakers \\
\hline 857 & 2.20 & .17 & .47 & .35 & .01 & .00 & electrical linemen \\
\hline 833 & 2.19 & .20 & .41 & .39 & .00 & .00 & machine-tool setter-operators \\
\hline 922 & 2.18 & .22 & .39 & .38 & .00 & .00 & printing pressmen \\
\hline 879 & 2.18 & .15 & .53 & .32 & .00 & .0 & fitters \\
\hline 931 & 2.17 & .21 & .42 & .37 & .00 & .0 & painters \\
\hline 79 & 2.12 & .29 & .31 & .37 & .02 & .0 & patternmakers \\
\hline 83 & 2.06 & .2 & .5 & .27 & .00 & .0 & polishers \\
\hline 872 & 1.99 & .23 & .5 & .23 & .00 & .0 & welders \\
\hline 82 & 1.95 & $.2 \xi$ & .4 & .23 & .00 & .0 & stone cutters \\
\hline 72 & 1.87 & .3 & .5 & .18 & .0 & .0 & metal melters \\
\hline & 1.68 & .3 & .6 & .00 & .00 & .00 & stereotypers \\
\hline
\end{tabular}

NUMBER OF OCCUPATIONS LISTED $=52$ 


\section{Cluster 3}

ISCO GENE AGRI DOME TECH TRAN MEDI LABO ECON MILI JURI QUAR TEAC THEO KUNS

\begin{tabular}{|c|c|c|c|c|c|c|c|c|c|c|c|c|c|c|}
\hline $\begin{array}{l}014 \\
052 \\
061 \\
063 \\
064 \\
065 \\
071 \\
072 \\
073 \\
074 \\
076 \\
079 \\
593\end{array}$ & $\begin{array}{l}.15 \\
.02 \\
.01 \\
.00 \\
.00 \\
.00 \\
.00 \\
.26 \\
.14 \\
.04 \\
.04 \\
.08 \\
.24\end{array}$ & $\begin{array}{l}.05 \\
.05 \\
.00 \\
.00 \\
.00 \\
.00 \\
.00 \\
.00 \\
.00 \\
.00 \\
.01 \\
.04 \\
.00 \\
.000\end{array}$ & $\begin{array}{l}.02 \\
.00 \\
.00 \\
.00 \\
.00 \\
.00 \\
.09 \\
.26 \\
.00 \\
.09 \\
.06 \\
.19 \\
.08\end{array}$ & $\begin{array}{l}.37 \\
.37 \\
.00 \\
.00 \\
.00 \\
.00 \\
.00 \\
.01 \\
.04 \\
.01 \\
.01 \\
.04 \\
.00\end{array}$ & $\begin{array}{l}.01 \\
.00 \\
.00 \\
.00 \\
.00 \\
.00 \\
.00 \\
.00 \\
.00 \\
.00 \\
.00 \\
.00 \\
.00\end{array}$ & $\begin{array}{l}.29 \\
.40 \\
.98 \\
.99 \\
.82 \\
.98 \\
.88 \\
.36 \\
.83 \\
.83 \\
.77 \\
.49 \\
.53 \\
=13\end{array}$ & $\begin{array}{l}.07 \\
.11 \\
.00 \\
.00 \\
.18 \\
.02 \\
.00 \\
.00 \\
.00 \\
.00 \\
.01 \\
.05 \\
.03\end{array}$ & $\begin{array}{l}.02 \\
.04 \\
.01 \\
.01 \\
.00 \\
.00 \\
.00 \\
.02 \\
.00 \\
.01 \\
.00 \\
.07 \\
.06\end{array}$ & $\begin{array}{l}.00 \\
.00 \\
.00 \\
.00 \\
.00 \\
.00 \\
.00 \\
.00 \\
.00 \\
.00 \\
.00 \\
.00 \\
.0 C\end{array}$ & $\begin{array}{l}.00 \\
.00 \\
.00 \\
.00 \\
.00 \\
.00 \\
.00 \\
.00 \\
.00 \\
.00 \\
.00 \\
.00\end{array}$ & $\begin{array}{l}.00 \\
.00 \\
.00 \\
.00 \\
.00 \\
.00 \\
.00 \\
.07 \\
.00 \\
.01 \\
.04 \\
.01 \\
.02\end{array}$ & $\begin{array}{l}.01 \\
.00 \\
.00 \\
.00 \\
.00 \\
.00 \\
.02 \\
.02 \\
.00 \\
.01 \\
.05 \\
.02 \\
.03\end{array}$ & $\begin{array}{l}.00 \\
.00 \\
.00 \\
.00 \\
.00 \\
.00 \\
.00 \\
.00 \\
.00 \\
.00 \\
.00 \\
.00 \\
.00\end{array}$ & $\begin{array}{l}.00 \\
.00 \\
.00 \\
.00 \\
.00 \\
.00 \\
.00 \\
.00 \\
.00 \\
.00 \\
.01 \\
.00 \\
.00\end{array}$ \\
\hline
\end{tabular}

ISCO NUMBER DESCR

01426768 physical science techn.

0522571 bacteriologists

06125009 medical doctors

0634754 dentists

$064 \quad 378$ dental assistants

0652194 veterinarians

07182169 prof. nurses

07279413 nursing pers. n.e.c.

$073 \quad 1132$ prof. midwives

0746312 midwivery pers. n.e.c.

07625161 physiotherapists

07918922 medical related workers n.e.c.

59316778 medical assistants

NUMBER OF OCCUPATIONS LISTED $=13$

ISCO LEVEL PRIMA SECON INTERM HIGHER ACAD DESCR

Scientific education

\begin{tabular}{llllllll}
\hline 065 & 5.00 & .00 & .00 & .00 & .00 & 1.0 & veterinarians \\
063 & 4.99 & .00 & .00 & .00 & .01 & .99 & dentists \\
061 & 4.96 & .00 & .00 & .01 & .02 & .97 & medical doctors \\
052 & 4.82 & .00 & .04 & .02 & .03 & .92 & bacteriologists \\
Higher vocational. & & & & & \\
\hline 064 & 4.00 & .00 & .00 & .00 & 1.0 & .00 & dental assistants \\
076 & 3.66 & .01 & .03 & .27 & .69 & .01 & physiotherapists \\
073 & 3.54 & .09 & .04 & .10 & .77 & .00 & prof. midwives \\
Higher general & secondary/Preparatory & scientific/Intermediate vocational \\
\hline 071 & 3.24 & .00 & .00 & .75 & .24 & .00 & prof. nurses \\
079 & 3.23 & .01 & .16 & .46 & .34 & .03 & medical workers n.e.c. \\
014 & 3.16 & .05 & .14 & .41 & .39 & .01 & physical science technicians \\
074 & 2.93 & .02 & .05 & .91 & .02 & .00 & midwivery pers. n.e.c. \\
072 & 2.89 & .02 & .15 & .77 & .06 & .00 & nursing pers.n.e.c. \\
593 & 2.88 & .04 & .15 & .71 & .08 & .02 & medical assistants
\end{tabular}

NUMBER OF OCCUPATIONS LISTED $=13$ 


\section{Cluster 4}

ISCO GENE AGRI DOME TECH TRAN MEDI LABO ECON MILI JURI QUAR TEAC THEO KUNS

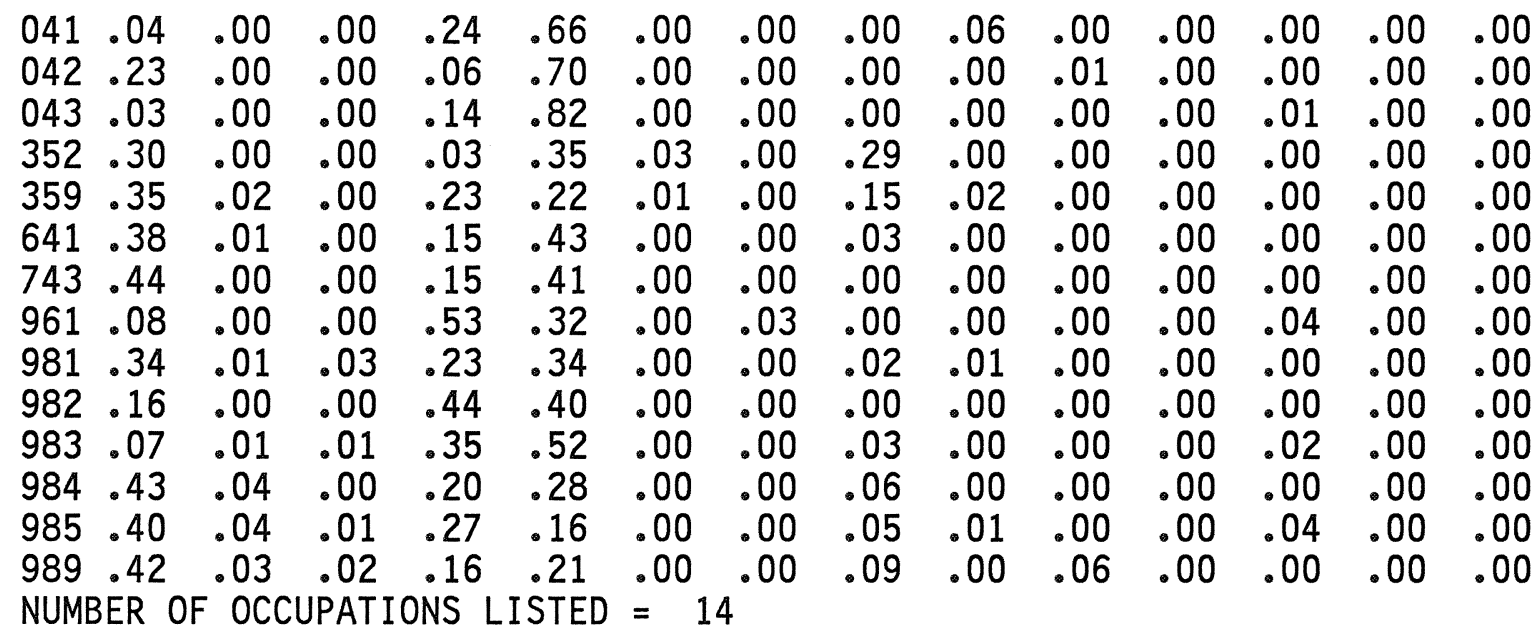

ISCO NUMBER DESCR

0412191 aircraft pilots

04210752 ships' deck officers and pilots

$043 \quad 3725$ ships' engineers

3521185 postmasters

35925417 transport supervisors n.e.c.

6413069 fishermen

743258 filter operators

9611607 power-generating machinery operators

9816246 ships' deck ratings

982680 ships' engine-room ratings

9835135 railway engine drivers

9842173 railway brakemen

985129971 motor vehicle drivers

9891430 transport equipment operators

NUMBER OF OCCUPATIONS READ $=14$ NUMBER OF OCCUPATIONS LISTED $=14$ 
ISCO LEVEL PRIMA SECON INTERM HIGHER ACAD DESCR

Higher vocational.

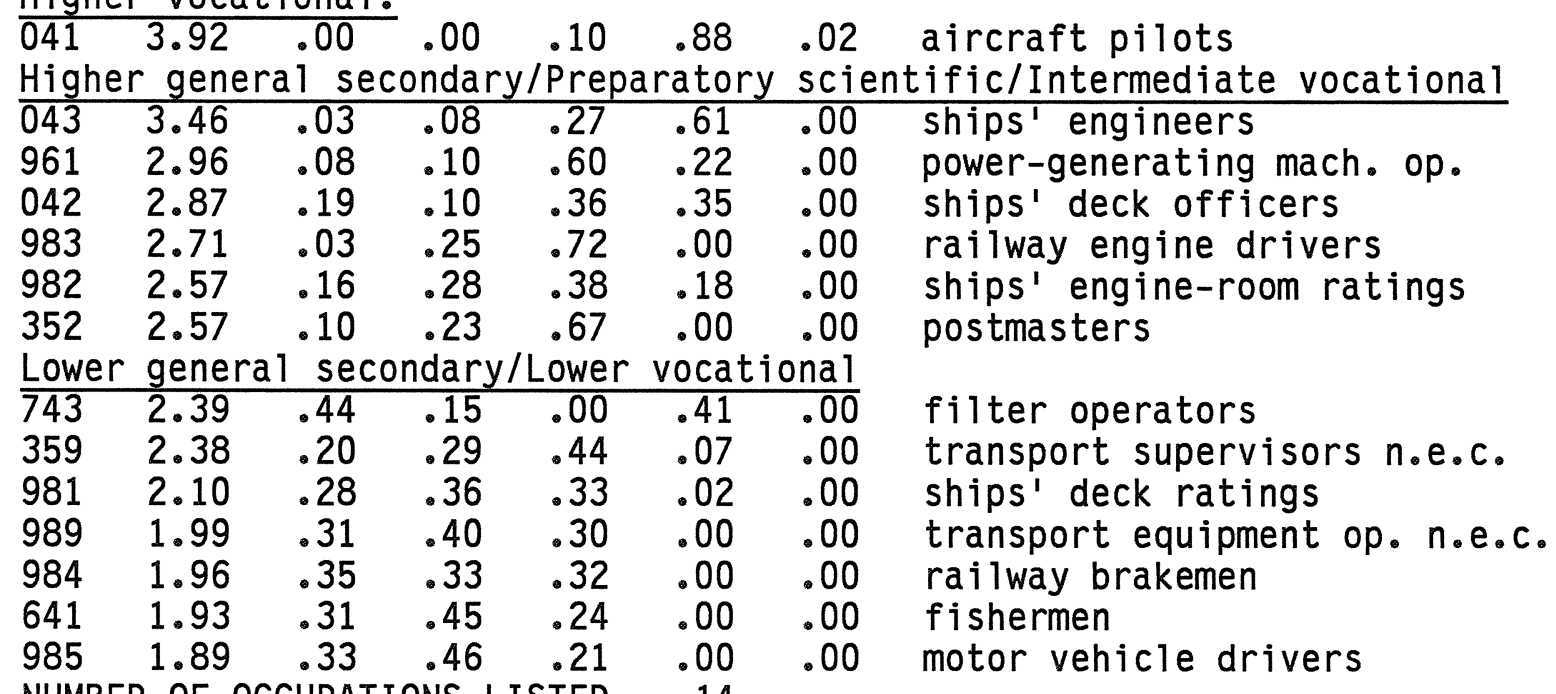

NUMBER OF OCCUPATIONS LISTED $=14$ 
Cluster 5

ISCO GENE AGRI DOME TECH TRAN MEDI LABO ECON MILI JURI QUAR TEAC THEO KUNS

\begin{tabular}{|c|c|c|c|c|c|c|c|c|c|c|c|c|c|c|c|}
\hline $\begin{array}{l}053 \\
601 \\
602 \\
609 \\
611 \\
612 \\
613 \\
631\end{array}$ & $\begin{array}{l}.00 \\
.12 \\
.20 \\
.09 \\
.20 \\
.13 \\
.09 \\
.12\end{array}$ & $\begin{array}{l}.98 \\
.66 \\
.61 \\
.85 \\
.71 \\
.73 \\
.78 \\
.79 \\
.62\end{array}$ & $\begin{array}{l}.01 \\
.00 \\
.00 \\
.00 \\
.01 \\
.01 \\
.00 \\
.00 \\
.00\end{array}$ & $\begin{array}{l}.01 \\
.09 \\
.10 \\
.02 \\
.03 \\
.04 \\
.03 \\
.00 \\
.05\end{array}$ & $\begin{array}{l}.00 \\
.00 \\
.00 \\
.00 \\
.00 \\
.00 \\
.00 \\
.00 \\
.03\end{array}$ & $\begin{array}{l}.00 \\
.05 \\
.00 \\
.00 \\
.00 \\
.00 \\
.00 \\
.00 \\
.00 \\
.00\end{array}$ & $\begin{array}{l}.00 \\
.00 \\
.00 \\
.00 \\
.00 \\
.00 \\
.00 \\
.00 \\
.00\end{array}$ & .1 & & & $\begin{array}{l}.00 \\
.00 \\
.00 \\
.00 \\
.00 \\
.00 \\
.00 \\
.00 \\
.00\end{array}$ & $\begin{array}{l}.00 \\
.00 \\
.00 \\
.00 \\
.00 \\
.00 \\
.00 \\
.00 \\
.00\end{array}$ & $\begin{array}{l}.00 \\
.00 \\
.02 \\
.00 \\
.00 \\
.00 \\
.00 \\
.00 \\
.00\end{array}$ & $\begin{array}{l}.00 \\
.00 \\
.00 \\
.00 \\
.00 \\
.00 \\
.00 \\
.00 \\
.00\end{array}$ & $\begin{array}{l}.00 \\
.00 \\
.00 \\
.00 \\
.00 \\
.00 \\
.00 \\
.00 \\
.00\end{array}$ \\
\hline
\end{tabular}

ISCO NUMBER DESCR

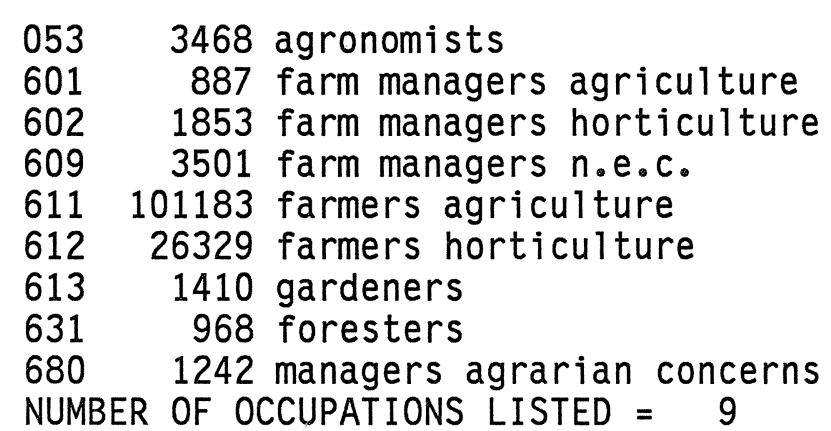

ISCO LEVEL PRIMA SECON INTERM HIGHER ACAD DESCR

Higher vocational.

$\begin{array}{llllllll}053 & 4.36 & .00 & .00 & .04 & .57 & .40 & \text { agronomists }\end{array}$

Higher general secondary/Preparatory scientific/Intermediate vocational

\begin{tabular}{|c|c|c|c|c|c|c|c|}
\hline 609 & $\begin{array}{l}2.88 \\
2.78 \\
2.66 \\
2.63 \\
2.52\end{array}$ & $\begin{array}{l}.08 \\
.07 \\
.09 \\
.05 \\
.07\end{array}$ & $\begin{array}{l}.17 \\
.29 \\
.20 \\
.37 \\
.34\end{array}$ & $\begin{array}{l}.55 \\
.45 \\
.68 \\
.51 \\
.59\end{array}$ & $\begin{array}{l}.17 \\
.16 \\
.04 \\
.05 \\
.00\end{array}$ & $\begin{array}{l}.02 \\
.02 \\
.00 \\
.03 \\
.00\end{array}$ & $\begin{array}{l}\text { farm managers } n_{\cdot} e_{\cdot c} \\
\text { managers agrarian concerns } \\
\text { gardeners } \\
\text { farm managers agriculture } \\
\text { foresters }\end{array}$ \\
\hline 02 & $\begin{array}{l}\text { genera } \\
2.47 \\
2.35 \\
2.23\end{array}$ & $\begin{array}{l}\text { sec } \\
.13 \\
.09 \\
.17\end{array}$ & $\begin{array}{l}\text { dary } \\
.31 \\
.48 \\
.44\end{array}$ & $\begin{array}{l}\text { Lower } \\
.51 \\
.43 \\
.37\end{array}$ & $\begin{array}{c}\text { vocati } \\
.04 \\
.01 \\
.02\end{array}$ & $\begin{array}{l}\text { ona } 1 \\
.00 \\
.00 \\
.00\end{array}$ & $\begin{array}{l}\text { farm managers horticulture } \\
\text { farmers horticulture } \\
\text { farmers agriculture }\end{array}$ \\
\hline
\end{tabular}

farmers agriculture 
Cluster 6

ISCO GENE AGRI DOME TECH TRAN MEDI LABO ECON MILI JURI QUAR TEAC THEO KUNS

$\begin{array}{lllllllllllllll}054 & .05 & .18 & .02 & .04 & .00 & .19 & .50 & .01 & .00 & .00 & .00 & .01 & .00 & .00 \\ 067 & .00 & .00 & .00 & .00 & .00 & .00 & 1.0 & .00 & .00 & .00 & .00 & .00 & .00 & .00 \\ 068 & .05 & .00 & .00 & .00 & .00 & .00 & .95 & .00 & .00 & .00 & .00 & .00 & .00 & .00 \\ 075 & .09 & .00 & .00 & .024 & .00 & .04 & .49 & .09 & .00 & .00 & .00 & .02 & .00 & .02 \\ 077 & .13 & .00 & .01 & .03 & .00 & .07 & .00 & .02 & .00 & .00 & .00 & .01 & .00 & .00\end{array}$

NUMBER OF OCCUPATIONS LISTED $=5$

ISCO NUMBER DESCR

05420056 life sciences technicians

067950 pharmacists

06810381 pharmaceutical assistants

0752092 optometrists

0775629 medical x-ray technicians

NUMBER OF OCCUPATIONS LISTED $=5$

ISCO LEVEL PRIMA SECON INTERM HIGHER ACAD DESCR

Scientific education

$\begin{array}{llllllll}067 & 4.87 & .00 & .00 & .04 & .04 & .92 & \text { pharmacists }\end{array}$

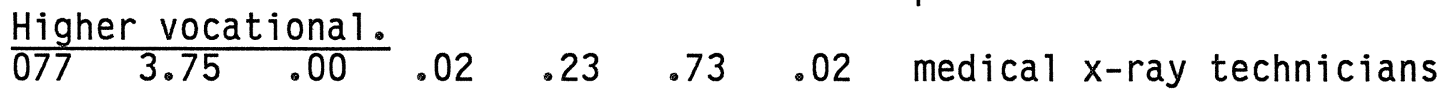

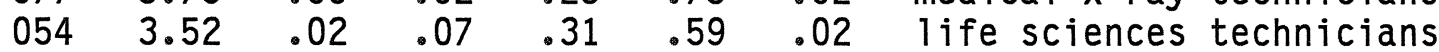

Higher general secondary/Preparatory scientific/Intermediate vocational

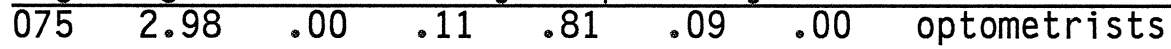

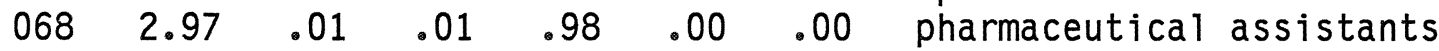

NUMBER OF OCCUPATIONS LISTED $=5$ 
Cluster 7

ISCO GENE AGRI DOME TECH TRAN MEDI LABO ECON MILI JURI QUAR TEAC THEO KUNS

069.03

$$
\begin{array}{lllll}
081 & .12 & .00 & .00 & .40 \\
085 & .10 & .00 & .00 & .34 \\
151 & .48 & .00 & .00 & .00
\end{array}
$$$$
\begin{array}{lllll}
151 & .48 & .00 & .00 & .00 \\
159 & .33 & .02 & .01 & .10
\end{array}
$$

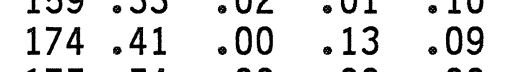

$\begin{array}{ll}.00 & .06 \\ .00 & .00\end{array}$

.01 .09 .00

$\begin{array}{lllll}.00 & .00 & .07 & .00 & .00 \\ .00 & .00 & .25 & .00 & .00\end{array}$

$.00 \quad .17$

.00 .22

$\begin{array}{lllll}.00 & .00 & .00 & .00 & .00\end{array}$

$.00 \quad .04$

$\begin{array}{lll}.04 & .04 & .04\end{array}$

175.54

179.23

199.15

201.13

202.10

211.17

213.17

310.07

322.37 .0

341.48

360.46

370.45

.00

.00 .00

.00 .0

$.02 .00 .16 \quad .00$

.00 .45

.00

$\begin{array}{llll}.00 & .00 & .12 & .00\end{array}$

.03

.20

.07

$.00 \quad .00$

380.49

391.41

$392 \cdot 30$

393.38

394.41

$\begin{array}{lll}.00 & .00 & .34 \\ .03 & .01 & .20\end{array}$

.00

.00 .34 .00

.03

.04

$\begin{array}{lll}.09 & .00 & .02\end{array}$

395.34

$\begin{array}{ll}399 & .41 \\ 420 & .38\end{array}$

436.15

.02 .01 .10

.00 .03

10.00

.20 .00

.00

00

.05

$.00 \quad .00 \quad .12$

.01 .01

.01 .01

00

17.

01

.09

.13

$.00 \quad .00 \quad .00$

$.00 \quad .00 \quad .23$

.00 .00

.00 .25 .00

.24

.09

$.04 \quad .01 \quad .01$

$\begin{array}{lll}.02 & .00 & .34 \\ .00 & .00 & .43\end{array}$

.01

.00

.32 .00

.24

.18

.11

.03 .00

.03 .00

$.00 \quad .00 \quad .12 .06$

.02

.04

$.00 \quad .00 \quad .00$

$.01 .00 \quad .05$

.00 .01

$.00 \quad .07 \quad .00$

.02 .02

$.01 .44 \quad .00$

.50

.14

.01

$.00 \quad .01$

$\begin{array}{llll}.02 & .00 & .39 & .00\end{array}$

$.00 \quad .00$

$\begin{array}{llll}.00 & .08 & .14 & .13\end{array}$

.00

.02

.14

.00

.00

.00

.03

$.00 \quad .01$

$\begin{array}{lllll}.06 & .00 & .00 & .13 & .01\end{array}$

.00

.00

.01

.00

.03

.00 .22

.03

.00

$.07 \quad .02$

.01

.26

.01

.01

.00

.01

.03

$.01 \quad .02$

.00

.35

.01

.00

$\begin{array}{llll}.01 & .02 & .02 & .01\end{array}$

.17

.01

.03

.01

.00

.02

.00 .00

.03 .00 .00

$\begin{array}{llll}.00 & .00 & .00\end{array}$

$\begin{array}{lll}.02 & .00 & .00\end{array}$

$\begin{array}{lll}.00 & .00 & .00\end{array}$

$\begin{array}{lll}.02 & .00 & .00\end{array}$

$\begin{array}{lll}.03 & .00 & .00\end{array}$

$.02 \quad .00 \quad .00$

$\begin{array}{lll}.03 & .01 & .00\end{array}$

$.06 \quad .16$

$.00 \quad .04$

481 .

482.49

490.40
502.34

518.44 .10

520.18

531.30

532.45

541.43

\subsection{6}

560.53

570.09

.09

$.01 \quad .12$

.02 .01

.00

$.17 \quad .03$

.03

.04

.03

$.00 \quad .00$

$\begin{array}{lllll}.01 & .00 & .00 & .31 & .00\end{array}$

.00

.36

.01

.00 .00

.41
.26

.00

.01

.00

$.01 .00 \quad .00$

.02

.00

.37

.00

.01

.00

.01

$.00 \quad .00$

$\begin{array}{llll}.00 & .00 & .00\end{array}$

$.00 \quad .36$

$\begin{array}{lll}.04 & .00 & .00\end{array}$

.37

.00

.00

.00 .00

$\begin{array}{lll}.02 & .21 & .09\end{array}$

.00 .01

$\begin{array}{lll}.00 & .27 \quad .00\end{array}$

.00

.00

.01

.01

$.00 \quad .01$

$.12 \quad .12$

.00

.01

$.00 \quad .23$

.00

.00

.00

.01

$.00 \quad .00$

$.00 \quad .08$

.10

.01

.00 .34

.00

.01

.02

.19

.00 .00

$\begin{array}{llll}.04 & .00 & .00 & .24\end{array}$

.00

.00

.00

.05

.00 .00

$$
\begin{array}{lll}
.01 & .29 & .09
\end{array}
$$

$.01 \quad .05$

$.01 \quad .22$

.01

.00

.11

.02

$.00 \quad .00$

$\begin{array}{lll}.01 & .47 & .09 \\ .00 & .30 & .06\end{array}$

$\begin{array}{llll}.00 & .01 & .00 & .10 \\ .00 & .01 & .00 & .16\end{array}$

.00

.00

.00

.00

$\begin{array}{llll}.01 & .02 & .00 & .08\end{array}$

.00

.00

.00

.0

$.00 \quad .00$

$\begin{array}{lll}.00 & .50 & .02\end{array}$

$\begin{array}{lll}.01 & .02 & .00 \\ .00 & .00\end{array}$

.06

.00

.00

.00

.03

$.00 \quad .00$

$.01 \quad .26$

$$
.09
$$

.01

.01 .00

.09

.00

.00

$\begin{array}{llll}592 & .38 & .09 & .03\end{array}$ 
ISCO NUMBER DESCR

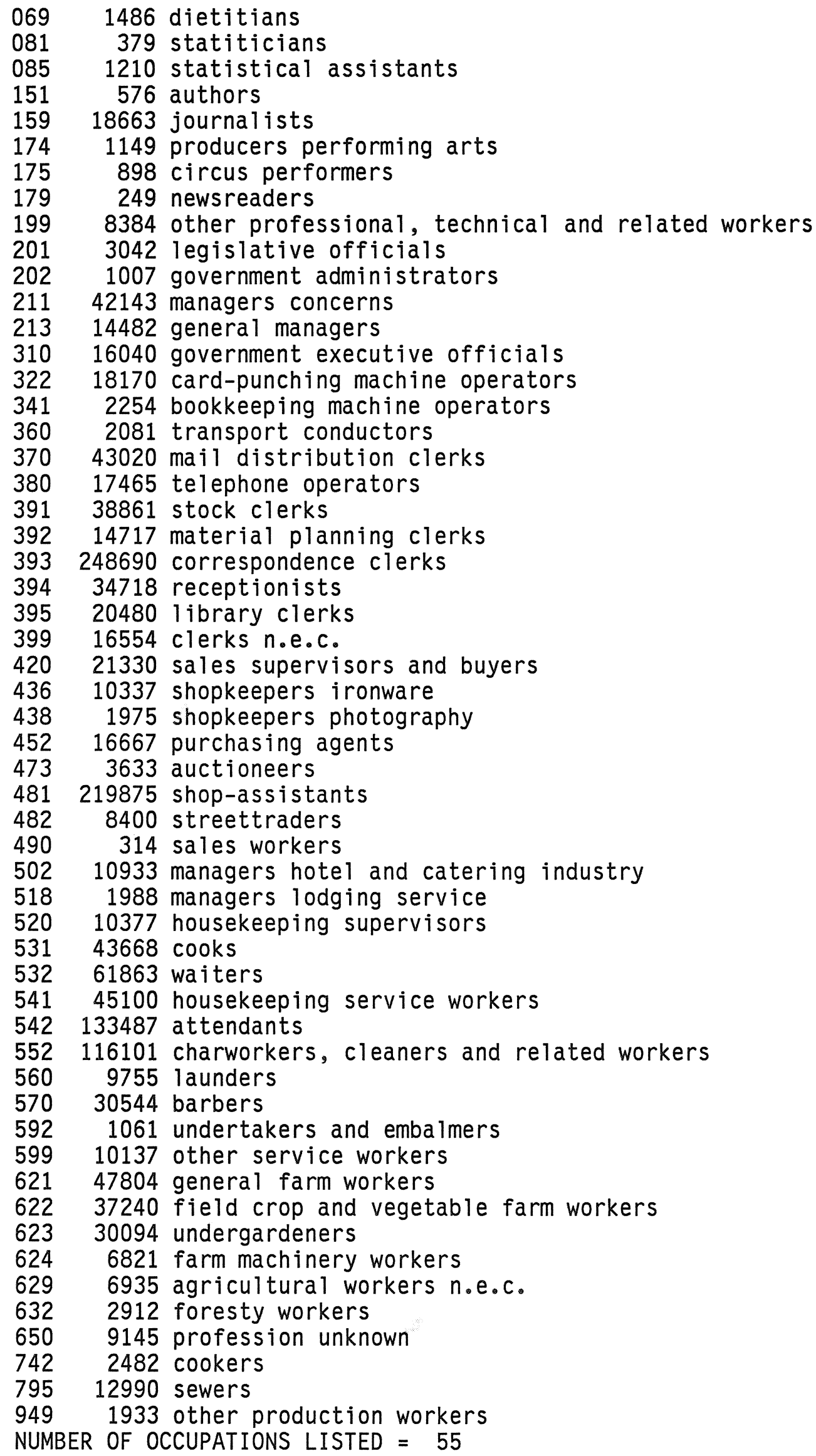


ISCO LEVEL PRIMA SECON INTERM HIGHER ACAD DESCR

Scientific education

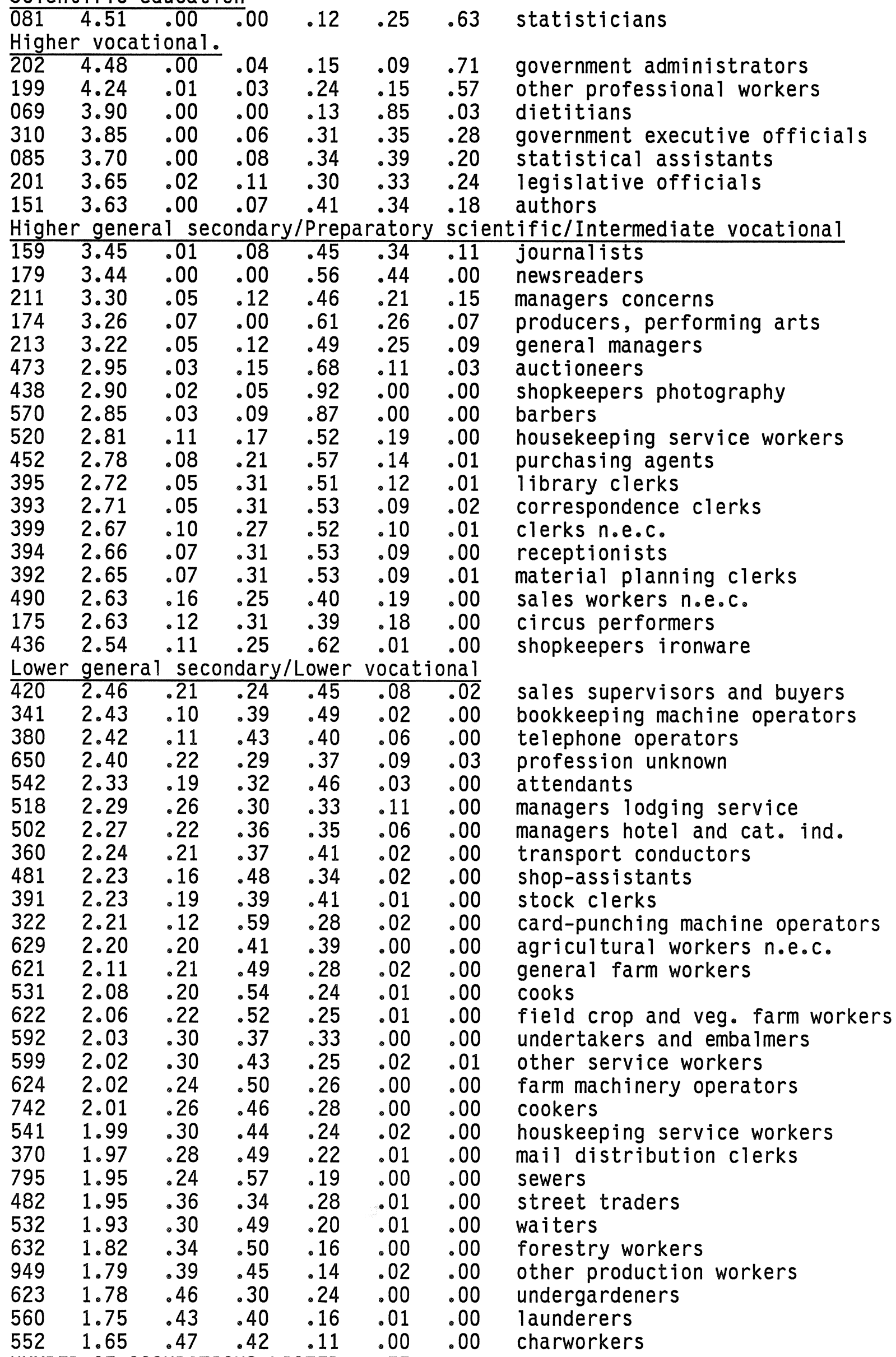


Higher vocational.

\begin{tabular}{llllllll}
\hline 090 & 4.00 & .01 & .03 & .28 & .33 & .35 & economists \\
110 & 3.98 & .00 & .05 & .29 & .28 & .38 & accountants \\
083 & 3.79 & .00 & .04 & .30 & .50 & .16 & system analysts \\
219 & 3.61 & .01 & .06 & .40 & .36 & .17 & managers n.e.c.
\end{tabular}

Higher general secondary/Preparatory scientific/Intermediate vocational

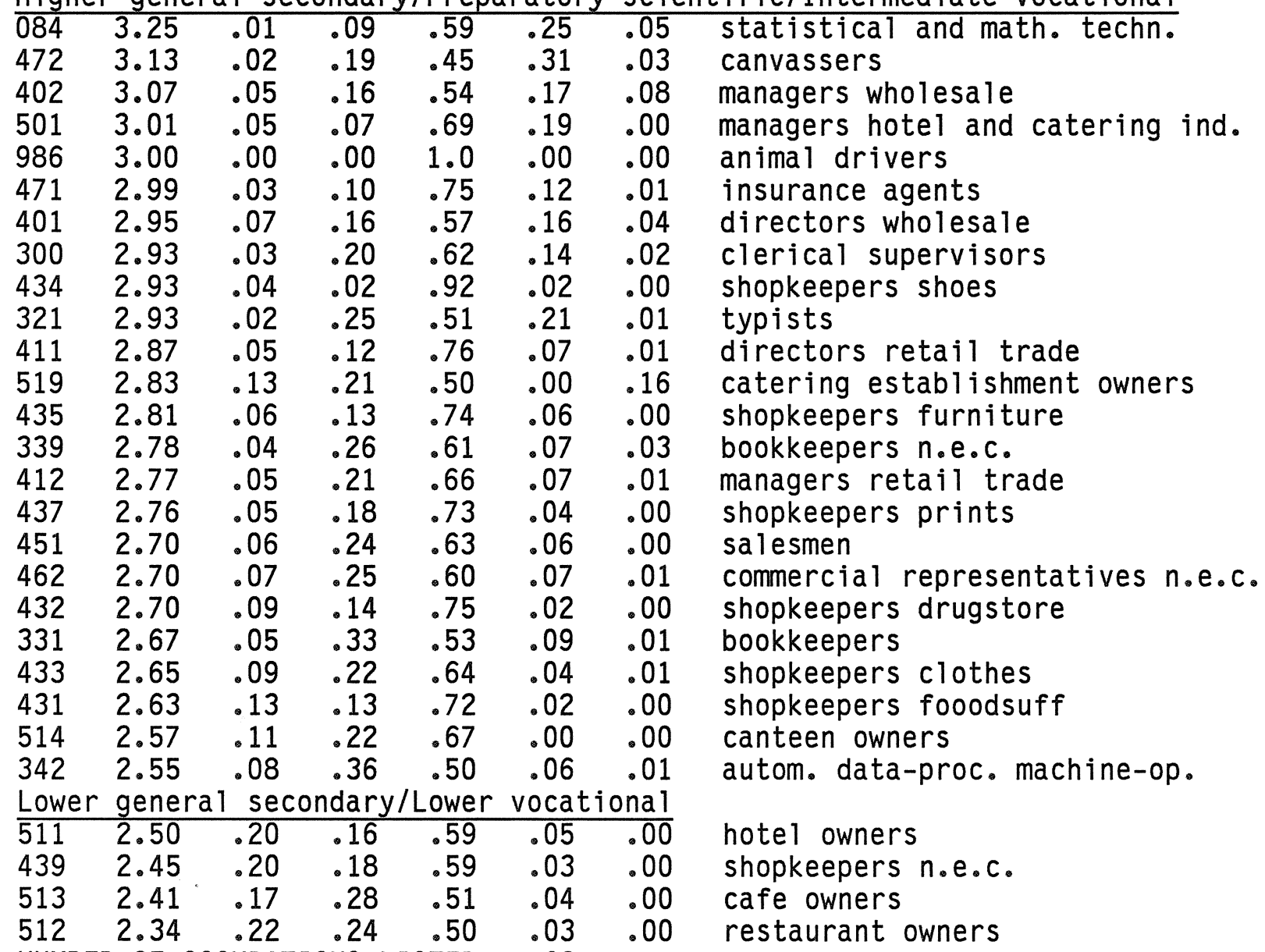

NUMBER OF OCCUPATIONS LISTED $=32$ 
ISCO NUMBER DESCR

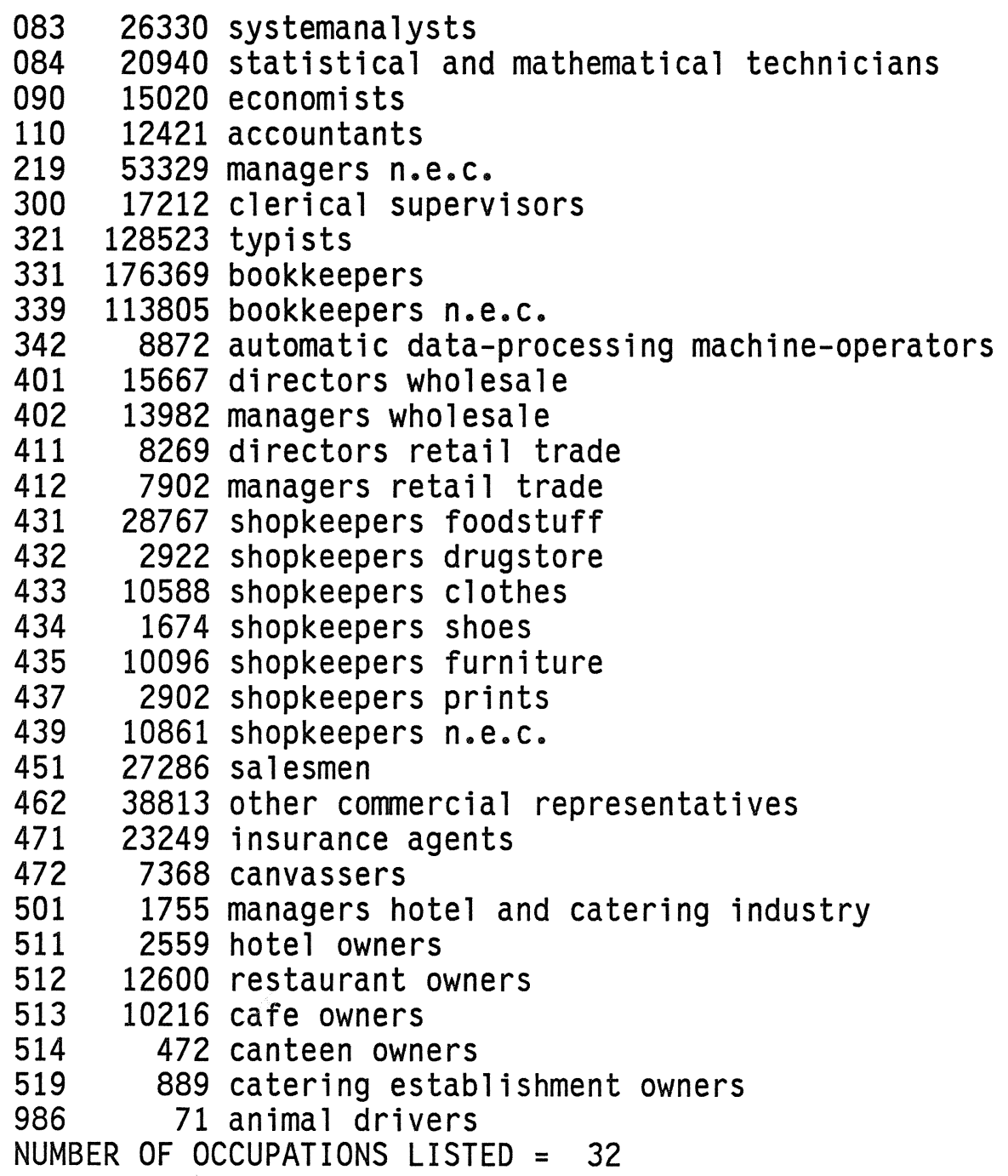




\section{Cluster 9}

ISCO GENE AGRI DOME TECH TRAN MEDI LABO ECON MILI JURI QUAR TEAC THEO KUNS

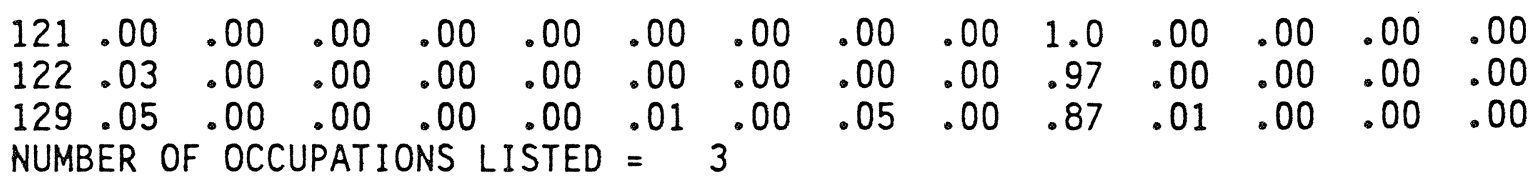

ISCO NUMBER DESCR

1213974 lawyers

122697 judges

12913747 jurists n.e.c.

NUMBER OF OCCUPATIONS LISTED $=3$

ISCO LEVEL PRIMA SECON INTERM HIGHER ACAD DESCR

Scientific education

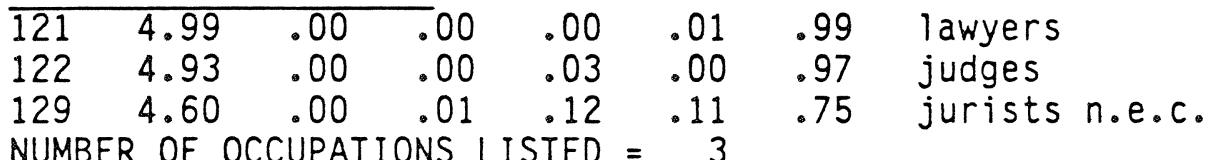

NUMBER OF OCCUPATIONS LISTED $=3$. 3 JUFists n.e.c. 


\section{Cluster 10}

ISCO GENE AGRI DOME TECH TRAN MEDI LABO ECON MILI JURI QUAR TEAC THEO KUNS

$\begin{array}{llllllllllllllll}131 & .02 & .01 & .00 & .09 & .00 & .02 & .00 & .03 & .00 & .01 & .13 & .67 & .01 & .02 \\ 133 & .00 & .00 & .00 & .00 & .00 & .00 & .00 & .00 & .00 & .00 & .01 & .99 & .00 & .00 \\ 134 & .00 & .00 & .00 & .00 & .00 & .00 & .00 & .00 & .00 & .00 & .01 & .98 & .00 & .00 \\ 135 & .00 & .00 & .00 & .00 & .00 & .00 & .00 & .00 & .00 & .00 & .00 & 1.0 & .00 & .00 \\ 139 & .06 & .01 & .01 & .11 & .01 & .03 & .00 & .07 & .03 & .03 & .16 & .46 & .01 & .02 \\ 172 & .17 & .00 & .02 & .00 & .00 & .00 & .00 & .10 & .00 & .00 & .03 & .51 & .00 & .17 \\ 180 & .18 & .01 & .08 & .12 & .00 & .05 & .00 & .13 & .02 & .03 & .00 & .37 & .00 & .00\end{array}$

NUMBER OF OCCUPATIONS LISTED $=7$

\section{ISCO NUMBER DESCR}

131142941 secundary and higher education teachers

13369310 primary education teachers

1348734 special education teachers

13523443 pre-primary education teachers

13927985 school principals

1722070 dancers

1807317 sportsmen

NUMBER OF OCCUPATIONS LISTED $=7$

ISCO LEVEL PRIMA SECON INTERM HIGHER ACAD DESCR

Higher vocational.

\begin{tabular}{llllllll}
\hline 131 & 4.23 & .00 & .01 & .05 & .64 & .30 & secundary and higher ed. teachers \\
133 & 4.00 & .00 & .00 & .01 & .98 & .01 & primary education teachers \\
134 & 4.00 & .00 & .00 & .01 & .97 & .02 & special education teachers \\
139 & 3.97 & .00 & .04 & .19 & .52 & .25 & school principals \\
Higher general secondary/Preparatory & scientific/Intermediate vocational \\
\hline 135 & 3.50 & .00 & .00 & .50 & .50 & .00 & pre-primary eduation teachers \\
172 & 3.30 & .02 & .07 & .52 & .34 & .04 & dancers \\
180 & 2.98 & .06 & .17 & .52 & .24 & .01 & sportsmen
\end{tabular}

NUMBER OF OCCUPATIONS LISTED $=7$ 
Cluster 11

ISCO GENE AGRI DOME TECH TRAN MEDI LABO ECON MILI JURI QUAR TEAC THEO KUNS

$\begin{array}{lllllllllllllll}141 & .02 & .00 & .00 & .01 & .00 & .00 & .00 & .02 & .00 & .00 & .01 & .01 & .92 & .01 \\ 149 & .08 & .00 & .00 & .00 & .00 & .00 & .04 & .00 & .03 & .00 & .10 & .16 & .59 & .00 \\ 161 & .18 & .00 & .04 & .06 & .00 & .01 & .01 & .09 & .01 & .00 & .00 & .07 & .00 & .53 \\ 162 & .15 & .11 & .02 & .21 & .00 & .00 & .00 & .16 & .00 & .00 & .01 & .02 & .00 & .33 \\ 171 & .12 & .00 & .02 & .02 & .00 & .01 & .00 & .03 & .00 & .00 & .00 & .11 & .00 & .69 \\ 173 & .01 & .00 & .05 & .00 & .00 & .00 & .00 & .00 & .00 & .00 & .06 & .24 & .00 & .44 \\ 591 & .12 & .00 & .00 & .00 & .00 & .00 & .00 & .00 & .00 & .00 & .00 & .23 & .00 & .36 \\ \text { NUMBER OF OCCUPATIONS LISTED }= & 7 & & & & & \end{array}$

ISCO NUMBER DESCR

1418435 ministers of religion

1491227 workers in religion n.e.c.

1616232 sculptors

16217330 commercial designers

$171 \quad 11028$ musicians

$173 \quad 1445$ actors

$591 \quad 361$ guides

NUMBER OF OCCUPATIONS READ $=7$ NUMBER OF OCCUPATIONS LISTED $=7$

ISCO LEVEL PRIMA SECON INTERM HIGHER ACAD DESCR

Scientific education

$\begin{array}{llllll}141 & 4.58 \quad .00 \quad .01 & .03 & .03 & .64 & \text { ministers of religion }\end{array}$

$\frac{\text { Higher vocational. }}{1494.10 .00} .00 \quad .28 \quad .34 \quad .38$ workers in religion n.e.c.

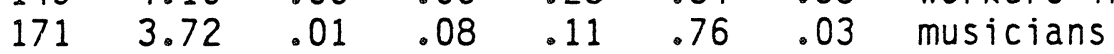

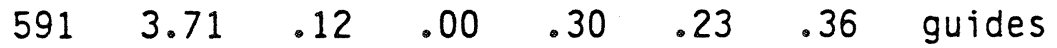

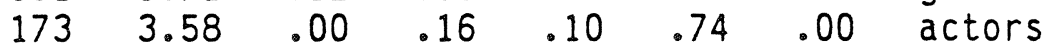

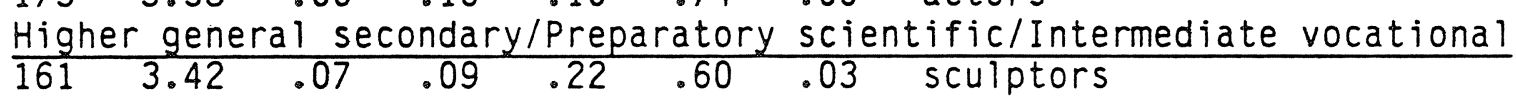

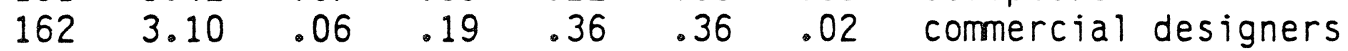

NUMBER OF OCCUPATIONS LISTED $=7$ 
Cluster 12

ISCO GENE AGRI DOME TECH TRAN MEDI LABO ECON MILI JURI QUAR TEAC THEO KUNS

$\begin{array}{lllllllllllllll}191 & .07 & .00 & .00 & .08 & .00 & .01 & .00 & .06 & .00 & .02 & .65 & .04 & .00 & .04\end{array}$

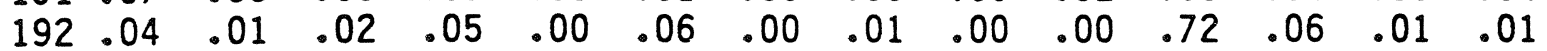

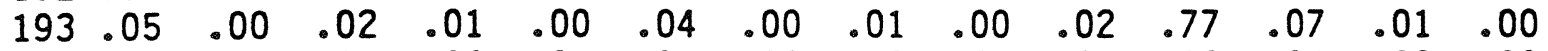

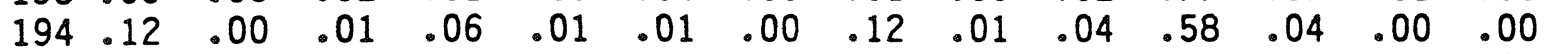

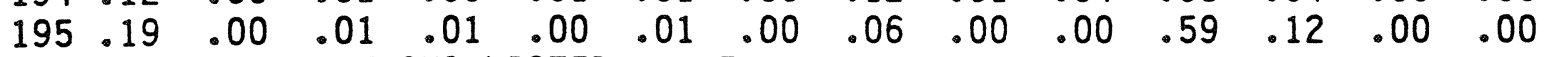

NUMBER OF OCCUPATIONS LISTED $=5$

ISCO NUMBER DESCR

19112490 librarians

19223619 sociologists

19348029 social workers

19410788 personnel specialists

1953547 philologists

NUMBER OF OCCUPATIONS LISTED $=5$

ISCO LEVEL PRIMA SECON INTERM HIGHER ACAD DESCR

Scientific education

$\begin{array}{lllllll}192 & 4.53 \quad .00 \quad .02 & .11 & .18 & .69 & \text { sociologists }\end{array}$

$\frac{\text { Higher vocational. }}{1954.03 \quad .03} .05 \quad .18 \quad .34 \quad .40$ philologists

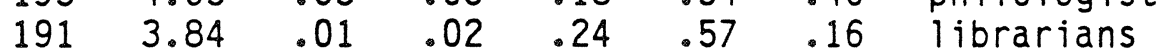

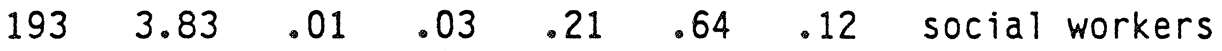

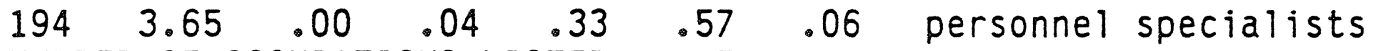

NUMBER OF OCCUPATIONS LISTED = 5 


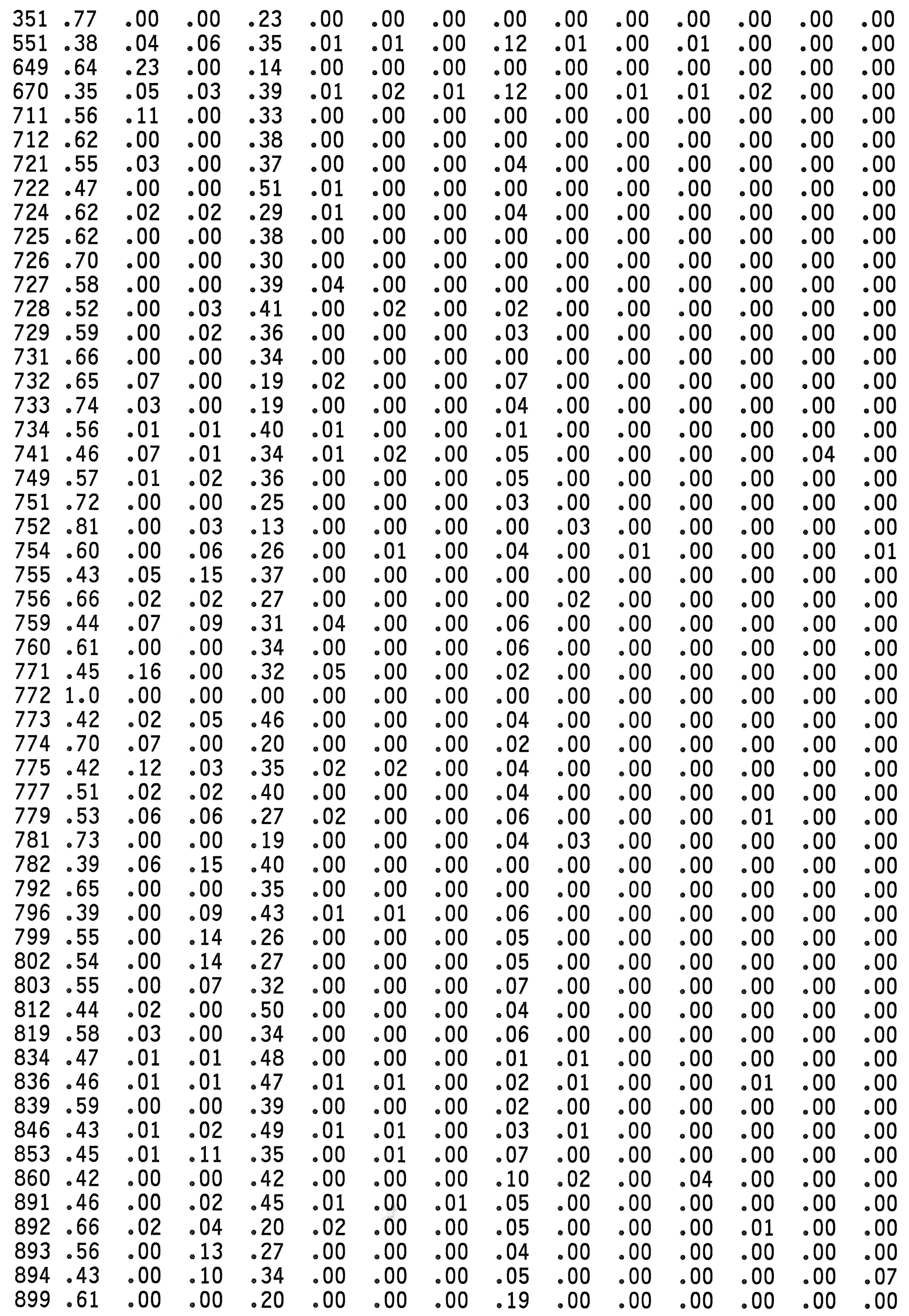




\begin{tabular}{|c|c|c|c|c|c|c|c|c|c|c|c|c|c|c|c|}
\hline $\begin{array}{l}901 \\
902 \\
910 \\
924 \\
926 \\
927\end{array}$ & $\begin{array}{l}.48 \\
.72 \\
.61 \\
.56 \\
.54 \\
.43 \\
.40 \\
.53 \\
.60 \\
.46 \\
.37 \\
.42 \\
.47 \\
.42 \\
.43 \\
.45 \\
.48 \\
.55 \\
.75 \\
.39 \\
.45 \\
.58 \\
.58 \\
.63 \\
.76 \\
.44 \\
.66 \\
\mathrm{FR}\end{array}$ & $\begin{array}{l}.05 \\
.01 \\
.01 \\
.00 \\
.00 \\
.00 \\
.00 \\
.00 \\
.06 \\
.01 \\
.02 \\
.03 \\
.01 \\
.00 \\
.01 \\
.01 \\
.04 \\
.04 \\
.00 \\
.03 \\
.06 \\
.04 \\
.09 \\
.04 \\
.00 \\
.00 \\
04\end{array}$ & $\begin{array}{l}.06 \\
.02 \\
.04 \\
.00 \\
.02 \\
.15 \\
.00 \\
.00 \\
.01 \\
.08 \\
.00 \\
.01 \\
.00 \\
.00 \\
.08 \\
.01 \\
.00 \\
.08 \\
.00 \\
.00 \\
.00 \\
.00 \\
.00 \\
.02 \\
.04 \\
.17 \\
03\end{array}$ & $\begin{array}{l}.34 \\
.24 \\
.29 \\
.41 \\
.39 \\
.31 \\
.54 \\
.30 \\
.30 \\
.33 \\
.57 \\
.52 \\
.51 \\
.53 \\
.45 \\
.44 \\
.43 \\
.21 \\
.00 \\
.49 \\
.41 \\
.25 \\
.29 \\
.24 \\
.15 \\
.40 \\
.23\end{array}$ & $\begin{array}{l}.01 \\
.00 \\
.00 \\
.00 \\
.00 \\
.00 \\
.01 \\
.00 \\
.01 \\
.01 \\
.00 \\
.01 \\
.00 \\
.00 \\
.00 \\
.00 \\
.01 \\
.02 \\
.14 \\
.05 \\
.05 \\
.10 \\
.01 \\
.01 \\
.01 \\
.00 \\
.01 \\
.0150\end{array}$ & $\begin{array}{l}.00 \\
.00 \\
.00 \\
.00 \\
.00 \\
.05 \\
.00 \\
.00 \\
.00 \\
.00 \\
.00 \\
.00 \\
.00 \\
.00 \\
.00 \\
.00 \\
.00 \\
.01 \\
.00 \\
.00 \\
.00 \\
.00 \\
.00 \\
.01 \\
.01 \\
.00 \\
.00 \\
=0\end{array}$ & $\begin{array}{l}.00 \\
.00 \\
.00 \\
.00 \\
.00 \\
.00 \\
.00 \\
.00 \\
.00 \\
.00 \\
.00 \\
.00 \\
.00 \\
.00 \\
.00 \\
.00 \\
.00 \\
.00 \\
.00 \\
.00 \\
.00 \\
.00 \\
.00 \\
.00 \\
.00 \\
.00\end{array}$ & $\begin{array}{l}.05 \\
.00 \\
.04 \\
.03 \\
.05 \\
.07 \\
.03 \\
.17 \\
.02 \\
.10 \\
.03 \\
.02 \\
.01 \\
.04 \\
.02 \\
.08 \\
.03 \\
.08 \\
.11 \\
.02 \\
.02 \\
.03 \\
.02 \\
.03 \\
.03 \\
.00 \\
.03\end{array}$ & $\begin{array}{l}.0 \\
.0 \\
.0 \\
.0 \\
.0 \\
.0 \\
.0 \\
.0 \\
.0 \\
.0 \\
.0 \\
.0 \\
.0 \\
.0 \\
.0 \\
.0 \\
.0 \\
.0 \\
.0 \\
.0 \\
.0 \\
.0\end{array}$ & $\begin{array}{l}.0 \\
.0 \\
.0 \\
.0 \\
.0 \\
.0 \\
.0 \\
.0 \\
.0 \\
.0 \\
.0 \\
.0 \\
.0 \\
.0 \\
.0 \\
.0 \\
.0 \\
.0 \\
.0\end{array}$ & & & $\begin{array}{l}.00 \\
.00 \\
.00 \\
.00 \\
.01 \\
.00 \\
.00 \\
.00 \\
.00 \\
.01 \\
.00 \\
.00 \\
.00 \\
.00 \\
.00 \\
.00 \\
.00 \\
.00 \\
.00 \\
.00 \\
.00 \\
.00 \\
.00 \\
.01 \\
.00 \\
.00 \\
.00\end{array}$ & $\begin{array}{l}.0 \\
.0 \\
.0 \\
.0 \\
.0 \\
.0 \\
.0 \\
.0 \\
.0 \\
.0 \\
.0 \\
.0 \\
.0 \\
.0 \\
.0 \\
.0 \\
.0 \\
.0 \\
.0 \\
.0 \\
.0\end{array}$ & $\begin{array}{l}.0 \\
.0 \\
.0 \\
.0 \\
.0 \\
.0 \\
.0 \\
.0 \\
.0 \\
.0 \\
.0 \\
.0 \\
.0 \\
.0 \\
.0 \\
.0\end{array}$ \\
\hline
\end{tabular}

\section{ISCO NUMBER DESCR}

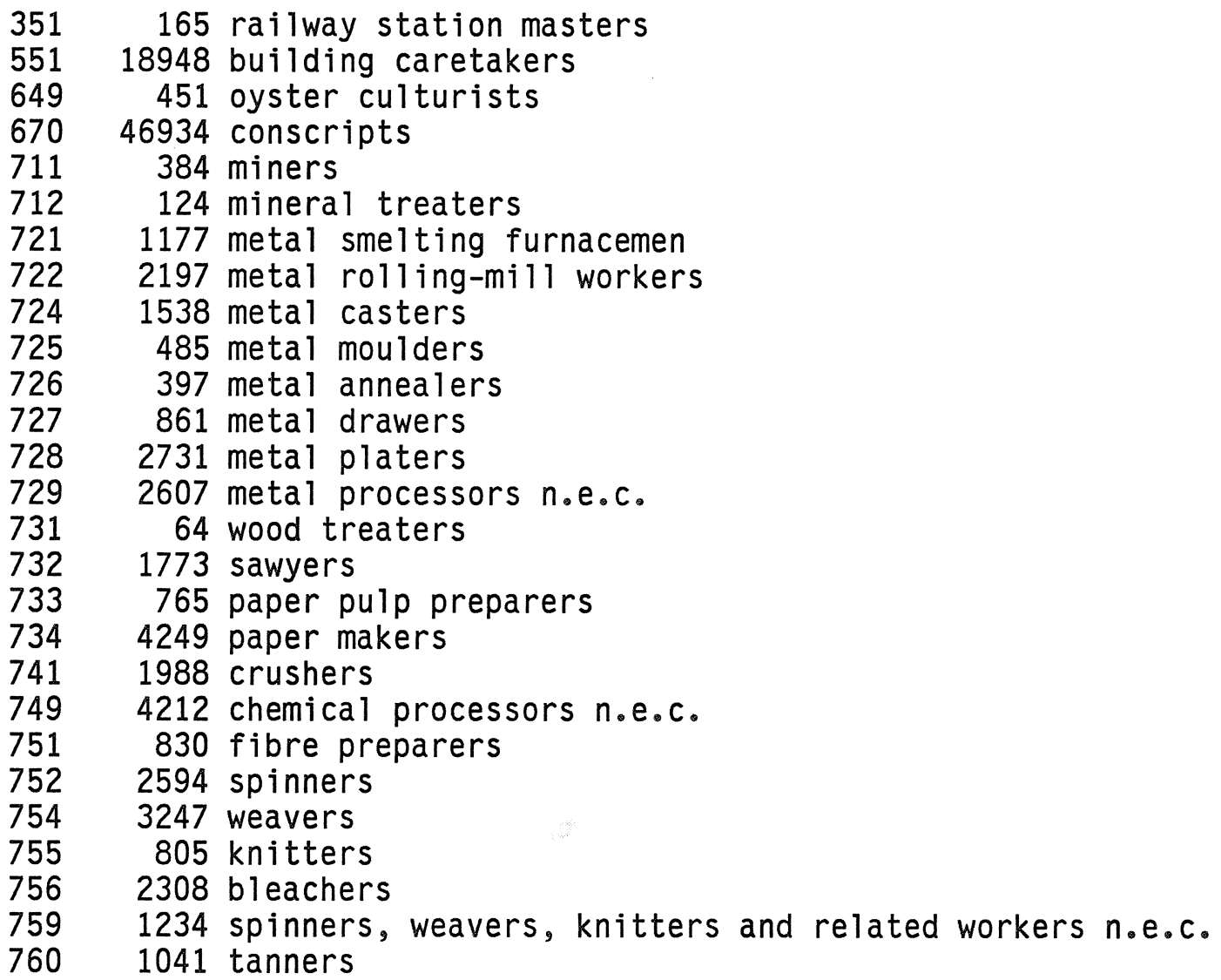




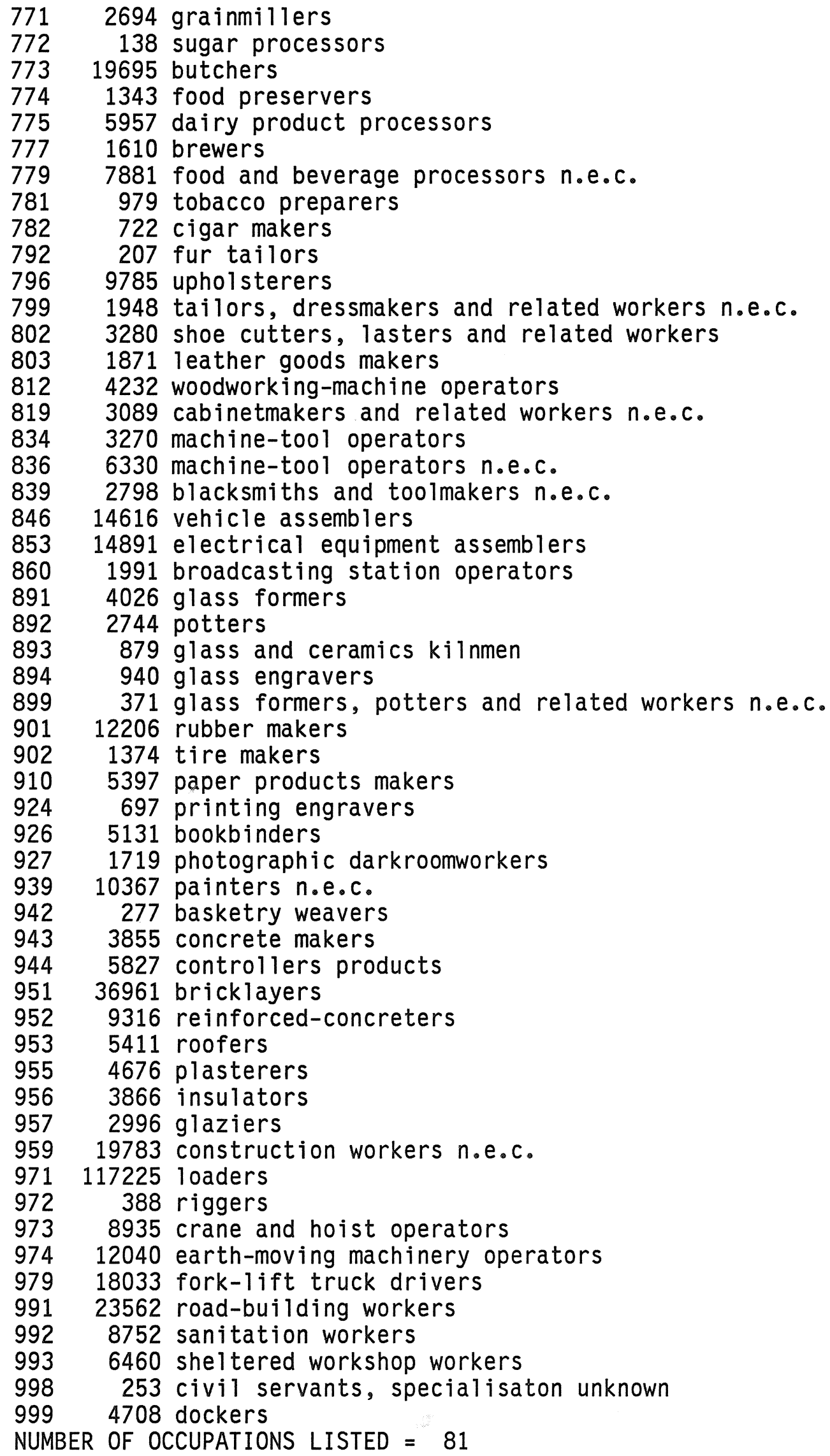


Higher general secondary/Preparatory scientific/Intermediate vocational

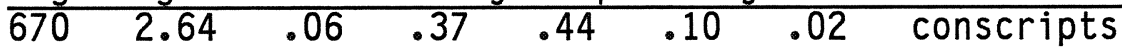

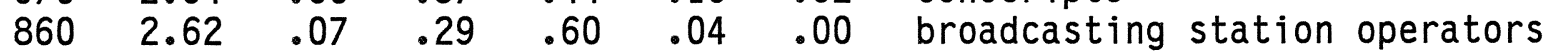

Lower general secondary/Lower vocational

$\begin{array}{llllllll}927 & 2.45 & .08 & .43 & .44 & .05 & .00\end{array}$

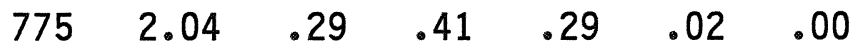

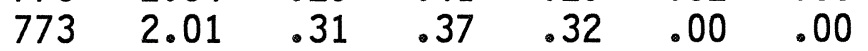

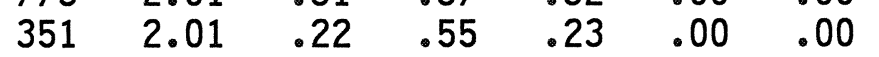

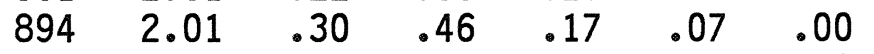

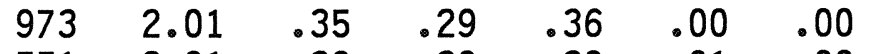

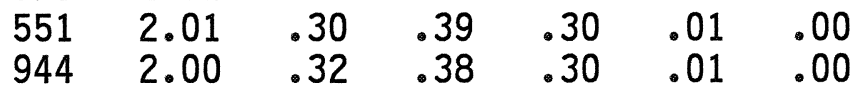

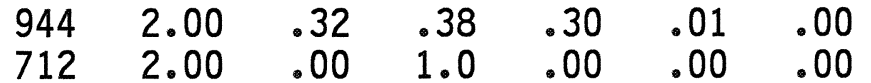

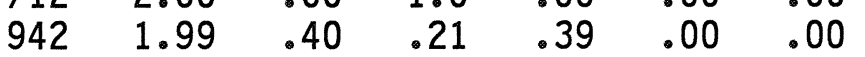

$\begin{array}{lllllll}998 & 1.96 & .44 & .17 & .40 & .00 & .00\end{array}$

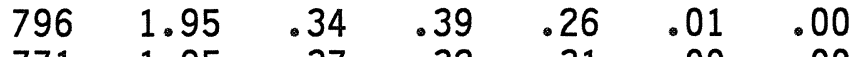

$\begin{array}{lllllll}771 & 1.95 & .37 & .32 & .31 & .00 & .00\end{array}$

$\begin{array}{lllllll}974 & 1.94 & .38 & .33 & .27 & .02 & .00\end{array}$

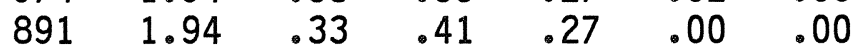

$\begin{array}{lllllll}939 & 1.90 & .35 & .39 & .25 & .00 & .00\end{array}$

$\begin{array}{lllllll}926 & 1.89 & .40 & .33 & .26 & .01 & .00\end{array}$

$\begin{array}{lllllll}741 & 1.89 & .39 & .37 & .20 & .04 & .00\end{array}$

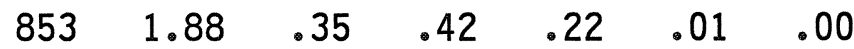

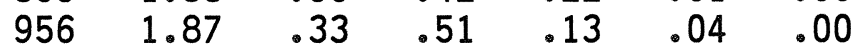

$\begin{array}{lllllll}812 & 1.87 & .39 & .35 & .26 & .00 & .00\end{array}$

$\begin{array}{lllllll}951 & 1.86 & .34 & .46 & .20 & .00 & .00\end{array}$

$\begin{array}{ll}722 & 1.85\end{array}$

.31

.52

.16

.00

.00

$846 \quad 1.84$

$.35 \quad .47$

.17

.01

.00

$749 \quad 1.82$

$.47 \quad .23$

$.17 \quad .00$

.00

$\begin{array}{lll}.30 & .00 \quad .00\end{array}$

$957 \quad 1.81$

$.40 \quad .40$

$.18 \quad .02$

.00

$959 \quad 1.81$

.41

.37

$.21 \quad .01$

.00

$901 \quad 1.81$

.36

.45

.18

.00

.00

$\begin{array}{ll}782 & 1.79\end{array}$

.33

.56

.12

.00

.00

$834 \quad 1.77$

.38

.47

.15

.00

.00

$.16 \quad .00 \quad .00$

1.77

.38

.46

.16

.01

.00

779
924

1.75

.38

.48

.14

.00

.00

$777 \quad 1.75$

.41

$.43 \quad .16$

.00

.00

.15

.01

.00

725

1.74

.42

.43

.15

1.72

.41

.45

.13

$.00 \quad .00$

$.00 \quad .00$

759

1.72

.41

.45

.15

.00

.00

892

1.71

.44

.25

.21

.00

.00

$.01 \quad .00$

.65

$.00 \quad .35$

.00

.00

731

1.70

.66

.00

.34

$.00 \quad .00$

$\begin{array}{ll}724 & 1.67\end{array}$

.46

.41

.00

.00

799

1.67

.38

.05

.00

.00

$.39 \quad .14$

$.00 \quad .00$

721

1.67

.44

$.44 \quad .12$

$.00 \quad .00$

$.43 \quad .11$

.00

.00

729

1.65

.46

.00

.00

732

1.65

.52

$.33 \quad .13$

.02

.00

photographic darkroomworkers

dairy product processors

butchers

railway station masters

glass engravers

crane and hoist operators

building caretakers

controllers

mineral treaters

basketry weavers

civil servants, spec. unknown

upholsterers

grainmillers

earth-moving machinery operators

glass formers

painters n.e.c.

bookbinders

crushers

electrical equipment assemblers

insulators

woodworking-machine operators

bricklayers

metal rolling-mill workers

vehicle assemblers

reinforced concreters

chemical processors n.e.c.

glaziers

construction workers n.e.c.

rubber makers

plasterers

cigare makers

machine-tool operators

machine-tool operators n.e.c.

food and beverage process. n.e.c.

printing engravers

brewers

loaders

metal moulders

roofers

spinners and related workers

paper makers

potters

fur tailors

wood treaters

metal casters

knitters

tailors and related workers

metal smelting furnacemen

miners

metal processors n.e.c.

sawyers

leather goods makers 


\begin{tabular}{lllllll}
728 & 1.64 & .47 & .42 & .11 & .00 & .00 \\
910 & 1.64 & .49 & .38 & .13 & .00 & .00 \\
943 & 1.63 & .54 & .31 & .14 & .01 & .00 \\
979 & 1.62 & .52 & .35 & .13 & .00 & .00 \\
839 & 1.62 & .51 & .36 & .13 & .00 & .00 \\
893 & 1.61 & .51 & .37 & .12 & .00 & .00 \\
754 & 1.61 & .54 & .32 & .13 & .01 & .00 \\
781 & 1.60 & .50 & .41 & .09 & .00 & .00 \\
649 & 1.60 & .64 & .13 & .24 & .00 & .00 \\
819 & 1.58 & .51 & .39 & .10 & .00 & .00 \\
992 & 1.58 & .57 & .28 & .15 & .00 & .00 \\
733 & 1.57 & .59 & .24 & .17 & .00 & .00 \\
991 & 1.57 & .54 & .35 & .11 & .00 & .00 \\
802 & 1.57 & .47 & .49 & .04 & .00 & .00 \\
999 & 1.54 & .56 & .34 & .10 & .00 & .00 \\
727 & 1.51 & .52 & .44 & .04 & .00 & .00 \\
756 & 1.51 & .60 & .29 & .11 & .00 & .00 \\
primary 1 School & & & & \\
\hline 972 & 1.49 & .75 & .00 & .25 & .00 & .00 \\
751 & 1.46 & .60 & .34 & .06 & .00 & .00 \\
774 & 1.45 & .63 & .31 & .04 & .02 & .00 \\
902 & 1.41 & .62 & .35 & .03 & .00 & .00 \\
760 & 1.39 & .61 & .39 & .00 & .00 & .00 \\
899 & 1.39 & .61 & .39 & .00 & .00 & .00 \\
752 & 1.38 & .71 & .20 & .09 & .00 & .00 \\
993 & 1.36 & .71 & .23 & .06 & .00 & .00 \\
726 & 1.30 & .70 & .30 & .00 & .00 & .00 \\
772 & 1.00 & 1.0 & .00 & .00 & .00 & .00 \\
NUMBER & $0 \mathrm{~F} 0 \mathrm{OCCUPATI}$ &
\end{tabular}

metal platers and coaters

paper product makers

concrete makers

fork-lift truck drivers

blacksmiths and toolmakers n.e.c. glass and ceramics kilnmen

weavers

tobacco preparers

fishermen

cabinetmakers and related workers sanitation workers

paper pulp preparers

road-building workers

shoe cutters and related workers

dockers

metal drawers

bleachers

riggers

fibre preparers

food preservers

tire makers

tanners

glass formers n.e.c.

spinners

sheltered workshop workers

metal annealers

sugar processers 
Cluster 14

ISCO GENE AGRI DOME TECH TRAN MEDI LABO ECON MILI JURI QUAR TEAC THEO KUNS

$\begin{array}{lllllllllllllll}581 & .07 & .00 & .00 & .18 & .00 & .01 & .00 & .01 & .73 & .00 & .00 & .00 & .00 & .00 \\ 582 & .05 & .00 & .00 & .02 & .01 & .00 & .00 & .00 & .01 & .00 & .00 & .01 & .00 & .00 \\ 589 & .28 & .02 & .02 & .02 & .01 & .01 & .00 & .08 & .33 & .05 & .01 & .00 & .00 & .00 \\ 660 & .21 & .01 & .01 & .022 & .02 & .00 & .00 & .04 & .01 & .00 & .00 & .03 & .00 & .00\end{array}$

ISCO NUMBER DESCR

5815121 fire-fighters

58231795 policemen

$589 \quad 18361$ protective service workers

66039294 soldiers

NUMBER OF OCCUPATIONS LISTED $=4$

ISCO LEVEL PRIMA SECON INTERM HIGHER ACAD DESCR

Higher general secondary/Preparatory scientific/Intermediate vocational

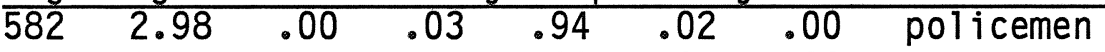

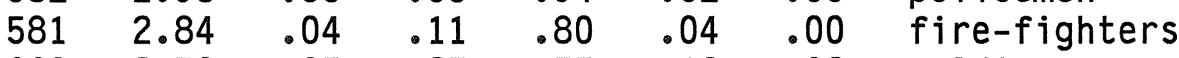

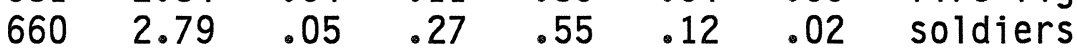

Lower general secondary/Lower vocational

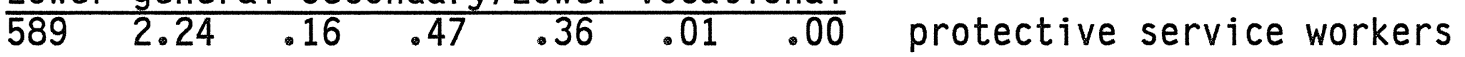

NUMBER OF OCCUPATIONS LISTED $=4$ 


\section{Cluster 8}

ISCO GENE AGRI DOME TECH TRAN MEDI LABO ECON MILI JURI QUAR TEAC THEO KUNS

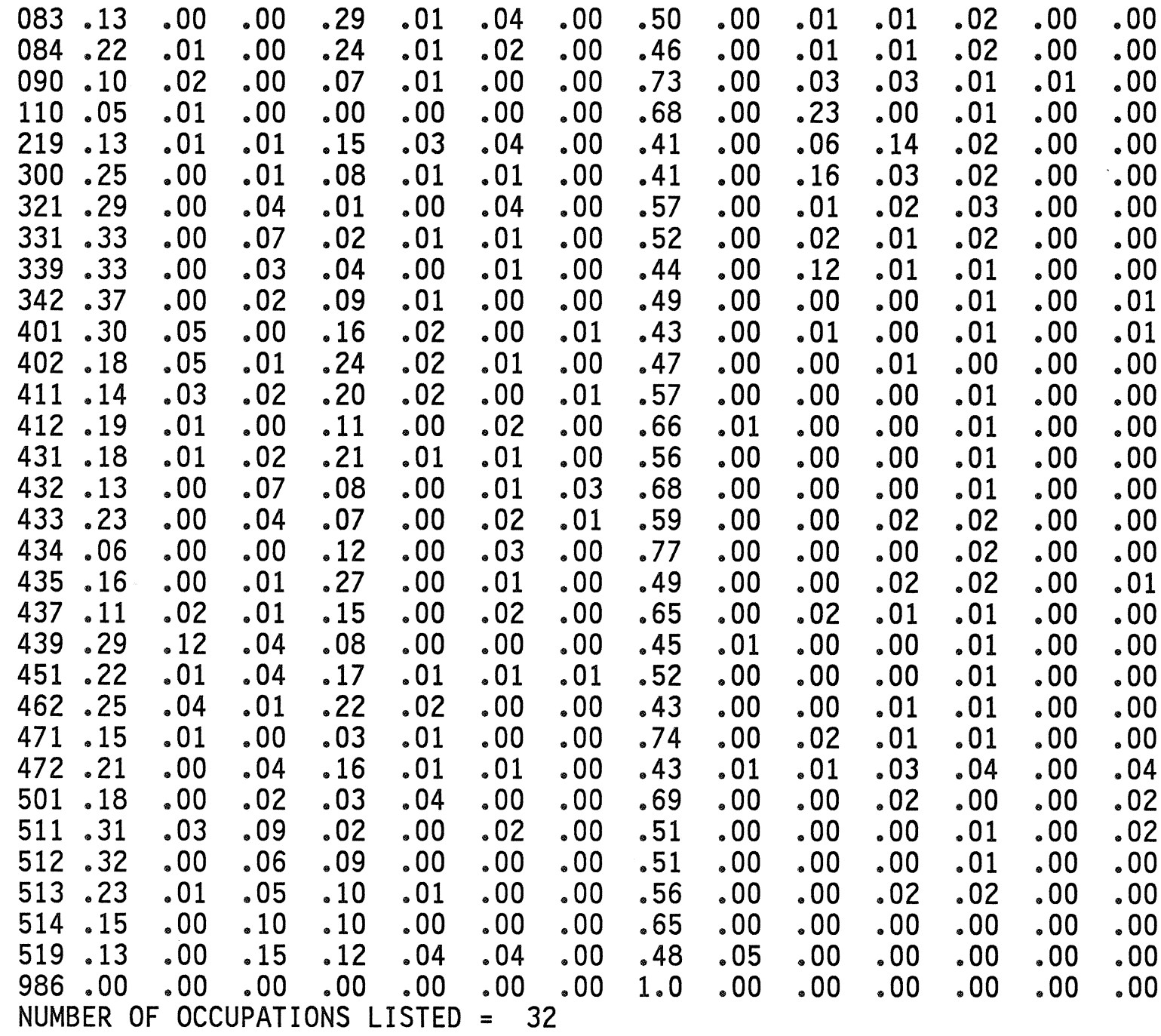


Cluster 10

ISCO GENE AGRI DOME TECH TRAN MEDI LABO ECON MILI JURI QUAR TEAC THEO KUNS

\begin{tabular}{|c|c|c|c|c|c|c|c|c|c|c|c|c|}
\hline $\begin{array}{ll}131 & .02 \\
133 & .00 \\
134 & .00 \\
135 & .00 \\
139 & .06 \\
172 & .17 \\
180 & .18\end{array}$ & $\begin{array}{l}.01 \\
.00 \\
.00 \\
.00 \\
.01 \\
.00 \\
.01\end{array}$ & $\begin{array}{l}.00 \\
.00 \\
.00 \\
.00 \\
.01 \\
.02 \\
.08\end{array}$ & $\begin{array}{l}.09 \\
.00 \\
.00 \\
.00 \\
.11 \\
.00 \\
.12\end{array}$ & $\begin{array}{l}.00 \\
.00 \\
.00 \\
.00 \\
.01 \\
.00 \\
.00\end{array}$ & $\begin{array}{l}.02 \\
.00 \\
.00 \\
.00 \\
.03 \\
.00 \\
.05\end{array}$ & $\begin{array}{l}.00 \\
.00 \\
.00 \\
.00 \\
.00 \\
.00 \\
.00\end{array}$ & $\begin{array}{l}.03 \\
.00 \\
.00 \\
.00 \\
.07 \\
.10 \\
.13\end{array}$ & $\begin{array}{l}.00 \\
.00 \\
.00 \\
.00 \\
.03 \\
.00 \\
.02\end{array}$ & $\begin{array}{l}.01 \\
.00 \\
.00 \\
.00 \\
.03 \\
.00 \\
.03\end{array}$ & $\begin{array}{l}.13 \\
.01 \\
.01 \\
.00 \\
.16 \\
.03 \\
.00\end{array}$ & $\begin{array}{l}.67 \\
.99 \\
.98 \\
1.0 \\
.46 \\
.51 \\
.37\end{array}$ & $\begin{array}{l}.01 \\
.00 \\
.00 \\
.00 \\
.01 \\
.00 \\
.00\end{array}$ \\
\hline
\end{tabular}

NUMBER OF OCCUPATIONS LISTED $=7$

ISCO NUMBER DESCR

131142941 secundary and higher education teachers

13369310 primary education teachers

1348734 special education teachers

13523443 pre-primary education teachers

13927985 school principals

$172 \quad 2070$ dancers

1807317 sportsmen

NUMBER OF OCCUPATIONS LISTED $=7$

ISCO LEVEL PRIMA SECON INTERM HIGHER ACAD DESCR

Higher vocational.

\begin{tabular}{llllllll}
\hline 131 & 4.23 & .00 & .01 & .05 & .64 & .30 & secundary and higher ed. teachers \\
133 & 4.00 & .00 & .00 & .01 & .98 & .01 & primary education teachers \\
134 & 4.00 & .00 & .00 & .01 & .97 & .02 & special education teachers \\
139 & 3.97 & .00 & .04 & .19 & .52 & .25 & school principals \\
Higher general secondary/Preparatory & scientific/Intermediate vocational \\
\hline 135 & 3.50 & .00 & .00 & .50 & .50 & .00 & pre-primary eduation teachers \\
172 & 3.30 & .02 & .07 & .52 & .34 & .04 & dancers \\
180 & 2.98 & .06 & .17 & .52 & .24 & .01 & sportsmen
\end{tabular}
NUMBER OF OCCUPATIONS LISTED $=7$ 
Cluster 11

ISCO GENE AGRI DOME TECH TRAN MEDI LABO ECON MILI JURI QUAR TEAC THEO KUNS

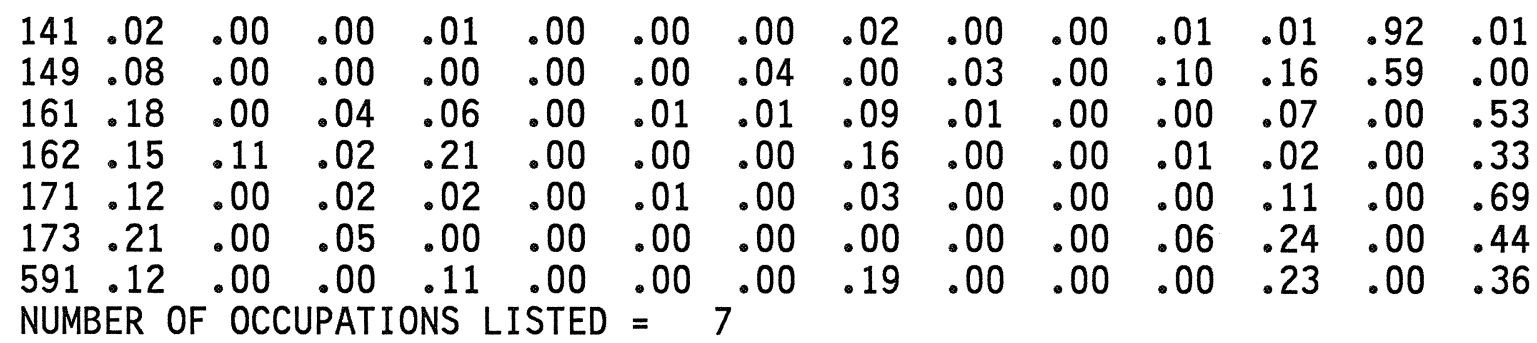

ISCO NUMBER DESCR

1418435 ministers of religion

1491227 workers in religion n.e.c.

1616232 sculptors

16217330 commercial designers

17111028 musicians

1731445 actors

$591 \quad 361$ guides

NUMBER OF OCCUPATIONS READ $=7$ NUMBER OF OCCUPATIONS LISTED $=7$

ISCO LEVEL PRIMA SECON INTERM HIGHER ACAD DESCR

Scientific education

\begin{tabular}{|c|c|c|c|c|c|c|c|}
\hline \multirow{2}{*}{\multicolumn{8}{|c|}{ ministers of religion }} \\
\hline & & & & & & & \\
\hline$\overline{149}$ & 4.10 & .00 & .00 & .28 & .34 & .38 & workers in religion n.e.c. \\
\hline 171 & 3.72 & .01 & .08 & .11 & .76 & .03 & musicians \\
\hline 591 & 3.71 & .12 & .00 & .30 & .23 & .36 & guides \\
\hline 173 & 3.58 & .00 & .16 & .10 & .74 & .00 & actors \\
\hline Higher & $r$ gene & al se & ondar & /Prepar & ratory & scient & tific/Intermediate vocational \\
\hline 161 & 3.42 & .07 & .09 & .22 & .60 & .03 & sculptors \\
\hline 162 & 3.10 & .06 & .19 & .36 & .36 & .02 & commercial designers \\
\hline
\end{tabular}

NUMBER OF OCCUPATIONS LISTED $=7$ 
Cluster 12

ISCO GENE AGRI DOME TECH TRAN MEDI LABO ECON MILI JURI QUAR TEAC THEO KUNS

$\begin{array}{llllllllllllllll}191 & .07 & .00 & .00 & .08 & .00 & .01 & .00 & .06 & .00 & .02 & .65 & .04 & .00 & .04 \\ 192 & .04 & .01 & .02 & .05 & .00 & .06 & .00 & .01 & .00 & .00 & .72 & .06 & .01 & .01 \\ 193 & .05 & .00 & .02 & .01 & .00 & .04 & .00 & .01 & .00 & .02 & .77 & .07 & .01 & .00 \\ 194 & .12 & .00 & .01 & .06 & .01 & .01 & .00 & .012 & .01 & .04 & .58 & .04 & .00 & .00 \\ 195 & .19 & .00 & .01 & .01 & .00 & .01 & .00 & .06 & .00 & .00 & .59 & .12 & .00 & .00\end{array}$

ISCO NUMBER DESCR

19112490 librarians

19223619 sociologists

19348029 social workers

19410788 personnel specialists

1953547 philologists

NUMBER OF OCCUPATIONS LISTED $=5$

ISCO LEVEL PRIMA SECON INTERM HIGHER ACAD DESCR

Scientific education

$\begin{array}{llllllll}192 & 4.53 & .00 & .02 & .11 & .18 & .69 & \text { sociologists }\end{array}$

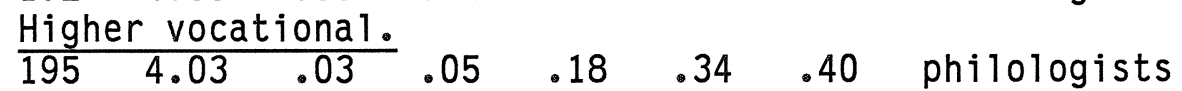

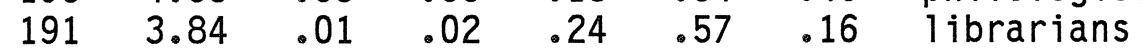

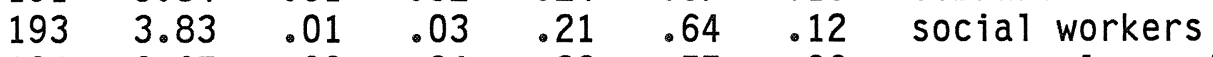

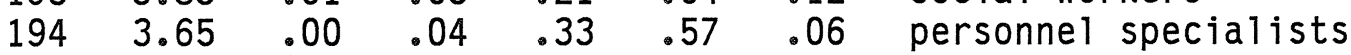

NUMBER OF OCCUPATIONS LISTED $=5$ 